\title{
Cognitive Effects of Aromatase and Possible Role in Memory Disorders
}

\section{OPEN ACCESS}

Edited by:

Gustavo M. Somoza, Instituto de Investigaciones Biotecnológicas (IIB-INTECH),

Argentina

Reviewed by:

Maria Julia Cambiasso, Instituto de Investigación Médica Mercedes y Martín Ferreyra (INIMEC),

Argentina

Emilio Domínguez-Salazar, Universidad Autónoma Metropolitana,

Mexico

${ }^{*}$ Correspondence:

Cheryl S. Rosenfeld

rosenfeldc@missouri.edu

Victoria J. Vieira-Potter vieirapotterv@missouri.edu

Specialty section:

This article was submitted to Neuroendocrine Science, a section of the journal

Frontiers in Endocrinology

Received: 20 August 2018 Accepted: 26 September 2018 Published: 17 October 2018

Citation:

Rosenfeld CS, Shay DA and Vieira-Potter VJ (2018) Cognitive Effects of Aromatase and Possible

Role in Memory Disorders.

Front. Endocrinol. 9:610.

doi: 10.3389/fendo.2018.00610

\author{
Cheryl S. Rosenfeld ${ }^{1,2,3 *}$, Dusti A. Shay ${ }^{4}$ and Victoria J. Vieira-Potter ${ }^{4 *}$ \\ ${ }^{1}$ Bond Life Sciences Center, University of Missouri, Columbia, MO, United States, ${ }^{2}$ Thompson Center for Autism and \\ Neurobehavioral Disorders, University of Missouri, Columbia, MO, United States, ${ }^{3}$ Biomedical Sciences, University of \\ Missouri, Columbia, MO, United States, ${ }^{4}$ Nutrition and Exercise Physiology, University of Missouri, Columbia, MO, \\ United States
}

Diverse cognitive functions in many vertebrate species are influenced by local conversion of androgens to $17 \beta$-estradiol (E2) by aromatase. This enzyme is highly expressed in various brain regions across species, with some inter-species variation in terms of regional brain expression. Since women with breast cancer and men and women with other disorders are often treated with aromatase inhibitors (Al), these populations might be especially vulnerable to cognitive deficits due to low neuroE2 synthesis, i.e., synthesis of E2 directly within the brain. Animal models have been useful in deciphering aromatase effects on cognitive functions. Consequences of Al administration at various life cycle stages have been assessed on auditory, song processing, and spatial memory in birds and various aspects of cognition in rodent models. Additionally, cognitive deficits have been described in aromatase knockout (ArKO) mice that systemically lack this gene throughout their lifespan. This review will consider evidence to date that Al treatment in male and female rodent models, birds, and humans results in cognitive impairments. How brain aromatase regulates cognitive function throughout the lifespan, and gaps in current knowledge will be considered, along with future directions to better define how aromatase might guide learning and memory from early development through the geriatric period. Better understanding the importance of E2 synthesis on neurobehavioral responses at various ages will likely aid in the discovery of therapeutic strategies to prevent potential cognitive deficits, including Alzheimer's Disease, in individuals treated with Al or those possessing CYP19 gene polymorphisms, as well as cognitive effects of normal aging that may be related to changes in brain aromatase activity.

Keywords: E2, brain, rodent models, breast cancer, Letrozole, Fadrozole, Alzheimer's Disease

\section{INTRODUCTION}

Aromatase is the enzyme responsible for all endogenous $17 \beta$-estradiol (E2) production in both males and females. Importantly, is it expressed in the brain as well as peripheral organs (i.e., gonads and adipose tissue). E2 has a diverse array of effects on brain development and function throughout the lifespan, including promoting development and maintenance of various cognitive abilities $(1,2)$; thus, it is not surprising that compounds designed to suppress aromatase can exert deleterious cognitive effects. Such cognitive effects of aromatase inhibition might vary according to species (e.g., learning and memory of vocalizations in songbirds) but there also are some consistencies across species that this review will highlight. This review will consider various 
cognitive effects in avian and rodent models, as well as the epidemiological evidence to date in humans, especially women, who received these chemicals and showed later cognitive impairments.

Women with breast cancer and individuals of both sexes with various other disorders (e.g., short stature in boys, infertility in men and women, endometriosis, leiomyomatosis, and Klinefelter syndrome) are increasingly being administered aromatase inhibitors (AI) to suppress conversion of androgens to estrogens (3-9). While such pharmacological therapies have been useful adjuvants in treating these disorders, there is mounting concern that systemic suppression of aromatase can lead to adverse health effects, especially cognitive dysfunction and other neurological symptoms (10-18). AI compounds that have been used in women and tested in animal models are Anastrazole (An), 1,4,6-androstatriene-3,17-dione (ATD), Exemestane, Fadrozole (FAD), Letrozole (Letro), and Vorozole. The chemical structures and molecular information are shown in Figure 1.

E2is considered essential in preserving normal brain function throughout life and may also play a role in recovery from brain injury or stress $(2,19-22)$. Early development brain programming is considered the organizational period and is characterized by rising concentrations of androgens, and aromatase conversion of androgens to estrogens within various brain regions (23-26), as detailed below. Timing is critical when considering how E2 affects brain development. As an example, most sex-dependent behaviors generally require a later resurgence of such steroid hormones ("activational period") to stimulate sex-specific neuronal pathways. AIs can disrupt this normal organizational-activational programming of the brain $(27,28)$. Unfortunately, most of the animal and human studies investigating the effects of AI on various outcomes related to cognitive processes are based on administration of AIs to adults. Thus, a topic that requires more study is how AI during early development, and even in utero (e.g., exposure during pregnancy of compounds that may advesely affect aromatase) may affect cognition during the lifespan.

In the case of rodents, studies have examined the effects of life-long aromatase deficiency using genetically modified mice that lack the Cyp19 gene, which encodes for the aromatase enzyme. Such mice lack the gene from the time of conception and throughout their lifespan (29-32). A limitation of those studies, as well as some human studies that have assessed genetic polymorphisms in Cyp19, is that it is often difficult to distinguish those effects that are directly due to aromatase inhibition within the brain vs. other organs, including the gonads, which might indirectly affect neural responses. Aromatase knock-out (ArKO) mice lack Cyp19 in all organs, including the brain; thus, cognitive disruptions observed in this model might be due to Cyp19 ablation within the brain and/or other organs. To address this issue, some rodent studies (discussed later) have directly infused aromatase into specific brain regions of gonadectomized animals. We will also discuss methods to disentangle the direct effects of aromatase inhibition in the brain vs. indirect effects due to suppression of this enzyme within other target organs.
In relation to the human studies, we also explore potential strategies, namely physical exercise, that might be useful in combating the memory and other neurological effects induced by AI. We consider the human epidemiological and animal model studies linking aromatase suppression or ablation with Alzheimer's disease (AD). Finally, we consider whether certain cognitive functions are influenced by aromatase suppression across taxa, discuss potential limitations of the current studies, and suggest future directions that are necessary to address the outstanding questions in this area that are increasingly becoming important with greater usage of such pharmacological agents. The focus of this review is the role of aromatase in regulating cognitive behaviors. Indeed, abundant literature implicates E2 in regulating various cognitive behaviors, especially in females $(1,2,19,33-35)$. It is, however, beyond the scope of the current work to delve into the various mechanisms by which estrogens might affect learning and memory, including through membrane and/or nuclear estrogen receptors (GPER, ESR1, and ESR2).

\section{AROMATASE EXPRESSION IN THE BRAIN: A BRIEF HISTORY AND OVERVIEW}

In 1971, Naftolin et al., first established the presence of aromatase in human fetal hypothalamus and within a few years developed the aromatization hypothesis, which describes the conversion of testosterone ( $\mathrm{T}$ ) to E2 via aromatase and its role in sexual differentiation of the brain (36). The second aromatization hypothesis that was put forward by two independent groups suggested that this enzyme was essential in the induction of masculine sexual behavior governed by E2 $(37,38)$. This enzyme has now been discovered in several other brain regions. Under physiological conditions, aromatase is constitutively expressed in the neurons of reptiles, birds, and mammals (35). In mammals, CYP19 expression/aromatase activity has been detected in the hypothalamus, medial preoptic area, bed nucleus of stria terminalis (BST), MeA, prefrontal cortex, hippocampus, and cerebellum $(35,39-46)$. Various brain regions of birds tend to express higher amounts of aromatase than in mammals, and thus avian models have greatly expanded our knowledge of how this enzyme regulates cognitive and other behavioral processes (35). Interestingly, studies examining the co-localization of aromatase mRNA and estrogen receptors in avian and mammalian species have demonstrated correlations between aromatase and estrogen receptor concentration, which differ based on species and brain region $(45,47,48)$.

\section{SPECIES AND SEX DIFFERENCES IN AROMATASE EXPRESSION AND ACTIVITY}

Male rats and mice tend to have higher levels of aromatase expression to convert androgens to estrogens to induce masculine sexual behavior $(46,49-51)$. However, the levels of aromatase expression and activity differ greatly across brain region and between sexes, in addition to differences in sensitivity to sex-hormone status across the lifespan. This sex difference 


\section{Pharmacological Aromatase Inhibitors}

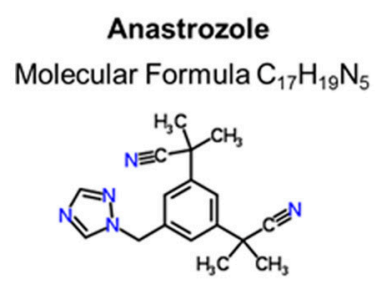

Fadrozole

Molecular Formula $\mathrm{C}_{14} \mathrm{H}_{13} \mathrm{~N}_{3}$

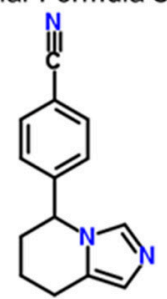

1,4,6-androstatriene-3,17-dione (ATD)

Molecular Formula $\mathrm{C}_{19} \mathrm{H}_{22} \mathrm{O}_{2}$<smiles>C[C@]12CC[C@]3(C)[C@@H]4[C@]3(C=CC3=CC(=O)C=C[C@@]34C)[C@@H]1CCC2=O</smiles>

Letrozole

Molecular Formula $\mathrm{C}_{17} \mathrm{H}_{11} \mathrm{~N}_{5}$

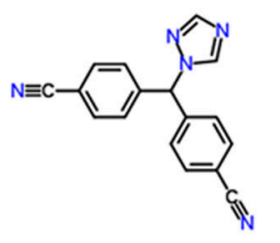

Exemestane

Molecular Formula $\mathrm{C}_{20} \mathrm{H}_{24} \mathrm{O}_{2}$

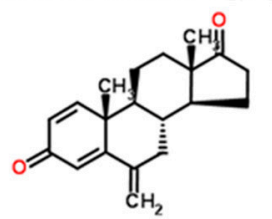

Vorozole

Molecular Formula $\mathrm{C}_{16} \mathrm{H}_{13} \mathrm{CIN}_{6}$

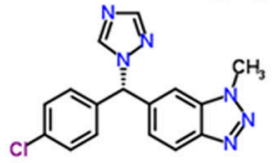

FIGURE 1 | Pharmacological inhibition of aromatase. These six compounds represent the primary ones used to inhibit aromatase activity in animals and humans. Chemical structures were generated from the ChemSpider webpage (http://www.chemspider.com/).

is most important in brain areas responsible for guiding sexual differentiation and regulating socio-sexual behaviors later in life, such as the hypothalamus and amygdala.

The affinity of brain aromatase to androgen substrates is identical in male and female quail brain (52). In avian species, varying patterns in brain aromatase expression are observed, which, again, differ by species and brain region examined. Male and female Japanese quail (Coturnix japonica) express similar Cyp19 mRNA levels in the medial preoptic area (MPOA) and mediobasal hypothalamus $(\mathrm{MBH})$, but females have reduced protein expression in the MPOA region (53, 54). In zebra finches (Taeniopygia guttata), females exhibit an increased number of aromatase-positive soma than males in the hypothalamus-preoptic area (HPOA) and caudomedial nidopallium (NCM) but fewer immuno-positive cell processes and synapses $(43,55)$. Similar results for aromatase activity have been reported in the synaptic terminals of female zebra finches (56). Relative to body size, avian species demonstrate substantially greater aromatase activity across most brain regions when compared to mammals $(35,52,57,58)$. Studies examining CYP19 mRNA expression patterns in humans have generated inconsistent results. Whereas Kadioglu et al. (59) and Sasano et al. (60) found no differences between male and female CYP19 mRNA expression across several brain regions examined, including pons, thalamus, hypothalamus, hippocampus, and amygdala.

In male rodents (e.g., Rattus norvegicus), ring doves (Streptopelia risoria), and Japanese quail, $\mathrm{T}$ and its metabolites regulate the long-term expression of aromatase in various brain regions, such as the amygdala, BNST, POA, and ventromedial nucleus of the hypothalamus, and medial preoptic nucleus (POM) (61-64). Both E2 and dihydrotestosterone (DHT) regulate Cyp19 mRNA levels only in XX mice independently of gonadal sex (46). On the other hand, in female rodents and birds, both T and E2 appear to regulate neural Cyp19 mRNA, protein, and activity levels $(62,65-72)$. In terms of non-genomic actions, cellular alterations in potassium, glutamate, and calciumdependent phosphorylation pathways have been shown to induce short-term changes in brain aromatase activity, as primarily shown in birds and rats $(35,73-82)$.

\section{COGNITION ASSESSMENT TECHNIQUES COMMONLY USED IN ANIMAL STUDIES}

To test cognitive ability in rodent models, most tests, such as the Barnes, Morris Water Maze (MWM), Y and radial arm mazes, measure spatial learning and memory. In such tests, individuals are repeatedly tested over a multi-day period, and their ability to locate an escape hole or maze arm that remains the same over the test is measured with the presumption that their latency to locate the correct hole or arm of the maze should decline with learning (83-85). Another common test to measure cognition in rodents is social recognition or their ability to differentiate novel animals of the same sex or different sex (86). The studies detailed below in ArKO mice, or rodents administered an AI, provide examples of results from such cognitive tests. Songbirds have been useful in examining how AI can affect learning as it relates to song vocalization, internal processing, and response rate, as these are key cognitive functions in this species. Other avian studies have measured the effects of AI on spatial learning and memory but with methods differing from those used in rodent studies. Such spatial studies are critical in bird species that cache their food over the winter period. 


\section{RODENT MODELS OF AROMATASE ABLATION/SUPPRESSION}

To examine the role of aromatase in various organs, including the brain, aromatase knockout ( $\mathrm{ArKO}$ ) mice have been created by two separate groups (29-32). Both ArKO mouse models have targeted deletion and insertion of a neomycin-resistance gene within exon 9 with a few more nucleotides replaced in the first model (29) compared to the second model generated (30). Even so, no studies have compared the two ArKO models in the same study to determine if there are subtle endophenotypic differences, and all of the studies detailed below are based on the first model. Both male and female ArKO mice show cognitive deficits when tested in a Y-maze to assess short-term spatial reference memory (87). Gonadectomy suppressed spatial responses of wild-type (WT) mice compared to that of intact ArKO counterparts, but this surgery did not exacerbate any impairments in ArKO mice relative to intact $\mathrm{ArKO}$ individuals. On the other hand, no changes in spatial learning ability were identified in adult ArKO female mice tested in the Morris water maze (MWM) even though increased expression of N-methyl-D-aspartase receptor subunit (Nr2b) was present in the hippocampus of female ArKO compared to WT mice (88). Based on these two studies, it is difficult to draw definitive conclusions as to whether ArKO mice demonstrate deficits in spatial learning and memory, although the latter study supports the notion that aromatase enzyme is important in initial male sexual differentiation as aromatase removal had no effect in females. The Y-maze assesses shortterm memory, whereas, the MWM measures spatial memory over a multi-day trial period. However, it could be argued that the MWM is not considered an ethologically relevant test for terrestrial rodents (89). A better approach might be to examine ArKO mice in the dry-land Barnes maze. It is also clear from other rodent studies that sex differences can exist in spatial learning and memory (90-92). Therefore, in future studies, both male and female ArKO mice should be tested in this maze and compared to their WT counterparts.

Potential socio-cognitive disruptions have also been examined in ArKO mice. Social recognition was diminished in ArKO male mice with associated reduction in arginine vasopressin (AVP, which as it is similar in structure to oxytocin can play a role in social behaviors and recognition)-immunoreactivity (IR) in several brain regions (93). Adult treatment with estradiol benzoate and dihydrotestosterone propionate (DHTP) restored this cognitive ability in gonadetomized ArKO males, which then showed rescue of their normal responses to female-oriented ultrasonic vocalizations, and were able to recognize unfamiliar females. Estradiol benzoate and DHTP treatment increased AVP-IR in the lateral septum of these males.

Olfactory discrimination ability is another important component in social cognition. WT males and ArKO males and females learned more rapidly to distinguish between urinary odors collected from gonadally intact males and estrous females compared to WT females (94). Of those groups, ArKO females were the quickest to acquire the ability to recognize volatile urinary odors from ovariectomized (OVX) and E2/progesterone vs. E2 alone-treated females. However, another study showed that while both ArKO and WT female mice can discriminate between odors of two different males, ArKO females failed to learn familiar male odors (95). This deficit might be due to reduced neurogenesis in the accessory olfactory bulb of ArKO females (95), suggesting that aromatase conversion of T to E2 is required for neuronal cell proliferation of this brain region in females. Taken together, the findings suggest that ArKO males may have decreased reproductive success because of impaired ability to distinguish individual female smells. However, ability to discern sex-differences in urinary odors appears to be enhanced in ArKO males and females with the latter possibility exhibiting masculinization of this trait. While females can discern male odors, they may exhibit memory impairments regarding familiar male odors, which could potentially also compromise their reproductive success. Moreover, synapse density is reduced in the hippocampus of female but not male ArKO mice (96). Thus, such enhanced responses in ArKO female might be due to ablation of central aromatase activity, i.e., E2 produced within the ovary, or due to masculinization in other brain regions. While such ArKO mice studies are helpful in discerning the role of brain aromatase in the case of gonadectomized individuals, these mice lack this enzyme throughout their lifespan, and thus, the effects of E2 deficiency at different critical time-periods, including at development vs. adulthood, cannot be distinguished. For such reasons, rodent models that use pharmacological inhibition of aromatase are the ideal choice to address such issues, at least until temporal and brain specific Cyp19 mice are generated. One such study that the administered the AI, ATD, to neonatal rats provides further support that aromatase is essential in male sexual differentiation of select neurons, such as those within the central portion of the vomeronasal projection circuit, and guiding later response to pheromonal cues (97). Other rodent studies testing various $\mathrm{AI}$ are detailed below.

In one study investigating working memory, adult female rats were OVX and then administered vehicle alone, testosterone propionate (TP) alone, Letro only or the combination of TP + Letro (98). Intact females demonstrated the best working memory in the object recognition test compared to all other groups with no differences among any of the OVX groups. The collective findings suggest that the observed cognitive responses are due to AI treatment primarily affecting ovarian rather than brain aromatase activity. Findings from other studies with intact male rats suggest that AI treatment might actually improve working memory. In one study, Sprague-Dawley adult male rats were orally administered Letro or vehicle (99). Unexpectedly, those treated with Letro committed fewer errors in a crossarms maze. The investigators concluded that Letro may improve egocentric working memory, which is where memories are encoded in how objects in space relate to position of oneself as opposed to allocentric- encoding of object information based on relation to other objects, by raising $\mathrm{T}$ levels. Adult male albino Wistar rats were administered the AI, An, directly into the CA1 region of the hippocampus (100). Other males were treated with testosterone enanthate (TE), E2 valerate (EV), or dimethylsulfoxide (DMSO, vehicle) alone. Those treated with the highest doses of TE or EV showed an increase in escape latency and traveled greater distance to find the invisible platform, 
whereas the AI, An, led to dose dependent decreases in escape latency and travel distance to find the hidden platform. These findings further indicate that $\mathrm{AI}$ in intact males might actually improve cognitive abilities, possibly by suppressing E2 synthesis.

Six- to eight-week old Swiss albino female mice were treated for 10-15 days with three different AIs that have different structures but similar potencies: An, Letro, or exemestane, and controls received just the vehicle solution. Both An and Letro but not exemestane suppressed learning and memory in the MWM. The behavioral changes correlated with expression levels for dickkopf1 ( $D k k 1$, an inhibitor of the WNT signaling pathway) and sclerostin (Sost, which is known to exert anti-anabolic effects on bone formation but uncertain CNS effects) in the hippocampus (101). Select studies have found strain or speciesspecific effects of AI, which could also depend upon dose of drug tested. While Letro treatment for 3 weeks induced anxietylike behaviors in OVX C57Bl6/6J mice, this treatment improved spatial learning and memory in the MWM (102). Young adult OVX Fischer-344 virgin female rats treated with An (showed no cognitive disturbances when tested in the water radial-arm maze (WRAM), delay match to sample (DMS) three choice task, MWM, and visible platform maze, tests designed to measure spatial and non-spatial working memory (103). Collectively, these studies do not provide a clear picture of how AI might affect these cognitive responses. The disparate responses across these studies are likely due to variation in the strain of mouse or rat tested, AI administered, dose and duration of treatment, and specific cognitive test. While each of these tests tend to measure hippocampal-memory, how the tests are conducted, age of the animals tested, and order of the behavioral tests are also important variables to consider.

Administration of Letro to adult C57Bl/6J male mice downregulated steroid receptor coactivator-1 ( $S r c 1$, which mediates transcriptional activity of nuclear receptors) in brain regions related to learning and memory integration and other behaviors, medial septa, hippocampus, medial habenular nucleus, arcuate hypothalamic nucleus, and superior colliculus (11). Circulating levels of $\mathrm{E} 2$ and gene expression of aromatase (i.e., $A r$ ), as well as E2 receptors alpha and beta (i.e., Esr1 and Esr2, respectively) were also decreased in the hippocampus of Letrotreated mice. Similarly, Letro treatment for 1 week to adult female Wistar rats suppressed $S r c 1$ and postsynaptic density protein 95 (Psd95) in the hippocampus (104). RNA interference with $S r c 1$ in in vitro culture of primary hippocampal neurons has been shown to inhibit $P s d 95$ gene and protein expression, suggesting that Src1 modulates the effects E2 synthesis of hippocampal synaptic plasticity via the synaptic protein PSD95.

To distinguish between the role of neural vs. the role of gonadal aromatase on cognitive responses, AIs have been administered directly into the brain of gonadectomized rodent models. Bilateral Letro infusion into the dorsal hippocampal region of OVX female rats immediately after training impairs hippocampal memory consolidation for object recognition and placement (105). This treatment also suppressed the surge in dorsal hippocampal E2 synthesis, generally observed $30 \mathrm{~min}$ after object training. Intracerebroventricular infusion of Letro into the brain of OVX rats did not affect learning responses in control individuals, but this treatment prevented exogenous estradiol treatment from enhancing hippocampal-dependent spatial memory acquisition in a radial-maze task (106). The combined findings from the two studies suggest that neuroE2 may be the primary mediator of certain types of cognitive responses, namely those relating to object recognition, but spatial learning and memory may depend on both neuro (direct production in the brain) and central (gonadal) E2 synthesis.

The collective data in rodents treated with AI have thus yielded conflicting findings as to whether this treatment affects cognitive responses. Potential conflicting data might be explained by differences in rodent strains used, sex, gonadectomized state, age at time exposure, specific AI administered, dose and duration of the treatment, and even which behavioral tests were used to assess learning and memory. Further work is also needed to determine whether developmental exposure of rodent models leads to long-term learning and memory deficits, as such treatment might disrupt organizational effects of T/E2 in the brain $(27,28,107)$. The current mouse and rat studies suggest that $S r c$ and secondarily, Psd 95 expression in the hippocampus might be vulnerable to AI treatment, and such effects could disrupt synaptic plasticity that is essential for cognitive traits. Presumably, there are other genes and brain regions involved in learning and memory that might be affected by AI, which should be the focus of future studies.

\section{AVIAN MODELS}

Although avian models have not been used for gene deletion studies, these species have been investigated in terms of responses to aromatase inhibition. E2 might be important in sensory processing in the auditory region of the songbird forebrain, termed the caudomedial nidopallium (NCM), as when birds hear conspecific song, a surge in local E2 occurs (108-112). Neurons in this region express high amounts of aromatase enzyme and E2 receptors (ESRs) (108-112). Treatment of adult male zebra finches ( $T$. guttata) with the AI, FAD (intramuscular injection of $100 \mu \mathrm{g}$ in $10 \mu \mathrm{l}$ of $0.75 \%$ saline), for 8 days resulted in reduced memory for training songs relative to saline-treated controls; however, auditory processing for novel songs did not differ between the two groups (113). The findings suggest that aromatase activity is required for neuronal memory for vocalizations in the songbird NCM. Similarly, acute aromatase inhibition with Vorozole $(30 \mathrm{mg} / \mathrm{kg})$ disturbed auditory processing in several brain regions selectively in the left hemisphere in male European starlings (Sturnus vulgaris) with the effects more prominent in March than in December or May/June for reasons that are uncertain (111). Photostimulated and E2-treated male European starlings exhibited a greater response rate to learn and respond to conspecific male song segments than those treated with saline or FAD $(8.4 \mathrm{mg} / 100 \mathrm{ml}$ avian saline in a micro-osmotic pump with a release rate of 0.25 $\mathrm{ml} / \mathrm{h})(114)$.

Male canaries (Serinus canaria) injected intraperitoneally with FAD within 2-5 min after the lights were turned on showed reduced motivation to sing and song acoustic stereotypy, an 
indicator of consistency over song renditions within a day's period, but all song measures returned to normal by the next day, suggesting that locally produced neuroE2 might act in a rapid manner to induce these learned vocal behaviors (115). Treatment of adult female canaries with FAD and testosterone induced song motor development resulted in changes in the song profile, and such alterations were linked with suppression of E2-sensitive transcripts, e.g., brain derived nerve growth factor (Bdnf) in the higher vocal center (HVC), but without altering the size of this brain region (116).

Other avian studies have examined the effects of AI on initial developmental brain programming. Treatment of juvenile male zebra finches with FAD (resulted in smaller neurons within the song motor centers- robust nucleus of the archistriatum (RA) and HVC but these histopathological changes were not associated with altered song behavior (117). Another study suggested FADtreatment of posthatching male zebra finches from days 1 to 30 was not associated with changes in soma size in both song motor centers (118). Female zebra finches treated as embryos on day 3 of incubation with FAD $(20 \mu \mathrm{g} / 5 \mu \mathrm{l}$ saline) had gonadal sex reversal with a left ovotestis and right testis, larger syrinx, but this treatment did not alter the volume and soma sizes in the song system nuclei (HVC and RA), which the investigators attributed to the fact that testicular androgens and E2 synthesis are insufficient to masculinize the song system in females, although this treatment had a small but significant effect in demasculinizing one aspect of the neural song system $(118,119)$. While there are seemingly conflicting data as to whether local aromatase is required for internalization (where songbirds learn their songs by imitating an internalized auditory song model or potential template acquired from a parental figure) and production of song, several factors, including species differences, timing of aromatase suppression (developmental or in adulthood), and dose of FAD tested, could account for the disparate results. It is also not clear if developmental or later exposure to AI alters brain regions associated with the song system. On the other hand, such auditory memory defects might be reversed with aromatization recovery during the breeding season. Conflicting data might also be attributed to species examined, dose and type of AI tested, timing of exposure, and specific brain region studied. Thus, across avian models, aromatase-mediated E2 production in the auditory processing region(s) (NCM) is critical in song vocalization. It would be of interest to determine in neonatal rodents, whether administration of AI compromises their potential ability to learn various vocalization responses, including ultrasonic vocalizations (USVs).

Aromatase suppression, especially directly within the brain, might result in other cognitive dysfunctions in birds. Adult male zebra finches were treated directly within the hippocampus with an AI, 1,4,6-androstatriene-3,17-dione (ATD), ATD +E2, or ATD + G protein-coupled E2 receptor (GPER) agonist G1, and spatial memory assessed $72 \mathrm{hrs}$ after the surgeries (120). Birds treated with ATD alone displayed compromised spatial memory, as evidenced by increased latency to reach a baited cup and made several mistakes in the process. However, cotreatment with E2 improved spatial memory as this group demonstrated the lowest retention latencies and made fewer mistakes. Those exposed to ATD and G1 resembled control animals. The post-synaptic protein (PSD95, a membraneassociated guanylate kinase important for synaptic strength) was lowest in the hippocampus of ATD-treated birds. Taken together, spatial memory in zebra finches is dependent upon local brain aromatase or neuroE2 and may act via GPERs. Conversely, treatment of non-breeding male and female Western scrubjays (Aphelocoma californica), a food-caching corvid possessing excellent spatial memory skills, with FAD and E2 implants suggest that E2 treatment suppressed spatial memory, including searching efficiency and latency to retrieve the first item (121). Another study reported that FAD-treatment of zebra finches impaired retrieval of spatial memory, whereas, spatial memory acquisition was enhanced when E2 production was blocked (122). The opposing results may be due to testing of breeding vs. non-breeding birds, along with species differences, timing of exposure, test used to measure spatial learning and memory, and/or sex differences, albeit these were not specifically examined for in the current studies.

\section{HUMAN AROMATASE STUDIES}

Aromatase activity affects brain and cognitive functions, not only across animal species, but in humans as well. This makes the animal studies cited above critical in lending insight into how aromatase activity and inhibition play a role in human cognition and behavior and diseases associated with such impairments. In the human brain, aromatase is particularly high in temporal and frontal brain areas; these regions are generally associated with learning, memory, and sensory processing (temporal lobes) and dopaminergic activity (frontal lobes). Interestingly, a 2006 study from the American Journal of Medicine identified relationships between sex steroid hormone gene polymorphisms and cognitive function in women and found important relationships that strongly implicate single nucleotide polymorphisms (SNPs) in genes associated with female sex steroids and cognition. Among them, subjects with a SNP in the aromatase gene (i.e., CYP19 rs936306 CC genotype) scored significantly lower on a memory test of repeated recall; on the other hand, other SNPs in this gene (e.g., rs72824 GG genotype) have been associated with higher memory scores (123). The avian studies detailed above suggest that CYP19 expression in the NCM $(43,74)$, a brain region associated with auditory discrimination and song recognition memory $(124,125)$, may regulate such processes. Similarly, CYP19A1 has been proposed to be a candidate gene regulating human cognitive functions associated with reading, speech, and language (126). This notion has been proposed based on the fact that examination of a Finnish, German, and several United States dyslexia cohorts reveals CYP19A1 expression in the human brain is positively correlated with dyslexia susceptibility genes, including dyslexia susceptibility 1 candidate 1 (DYX1C1) and roundabout homolog 1 (ROBO1) (126). Variations in CYP19A1 are also associated with dyslexia as a categorical trait and quantitative disruptions in reading, vocabulary, phonological processing, and oral motor skills (126). This same study also 
showed that ArKO mice have an increase in vertical neuronal density and occasional cortical heterotopia as observed in Robo1 mutant mice and human dyslexia brains, respectively.

Another study investigated associations between CYP19 gene polymorphisms with Alzheimer's disease (AD) (127). Although the vast majority of AI therapy is prescribed to treat breast cancer, this class of drugs can be used to treat other human clinical conditions. It has been prescribed to treat short stature in boys (128). Other conditions treated with AI include: infertility in women (129) and men (129), endometriosis (130), intravenous leiomyomatosis (131), and Klinefelter syndrome (132). Although one study tested the cognitive effects of AI in boys treated for short stature and found no relationship (133), more research is necessary to determine the long term effects of such therapies on cognitive function in both sexes and especially when administered at an early age.

Breast cancer is the most common cancer among women in the United States, and obesity, defined by excess adipose tissue, is a major risk factor (134). Since aromatase is highly expressed in adipose tissue, obese women experience greater E2 exposure than lean women, which renders them more susceptible to E2induced tumors (135). Moreover, obesity associates with adipose tissue inflammation, which stimulates aromatase activity; a topic that has been extensively reviewed (136). Even lean women who display increased breast adipose tissue inflammation present with greater aromatase activity and increased risk of breast cancer (135). Thus, AI therapy represents a cornerstone of breast cancer treatment. This is also because two-thirds of breast cancer cases are ER+ tumors that depend upon E2 for growth and survival. High expression of aromatase in mammary adipose tissue makes it the major contributor to local E2 exposure. Thus, AI are often prescribed to women diagnosed with breast cancer. Notably, obese women have been shown to be somewhat resistant to the effects of AI (137), which may result in these women being prescribed higher doses and thereby experiencing even more severe side effects.

Several negative cognitive side effects, such as difficulty concentrating and forgetfulness, are commonly reported among women in AI therapies (138). The main cognitive impairments associated with AI therapy are verbal episodic memory and executive function impairments (139). The mechanism by which AI induce cognitive deficits presumably involves suppression of E2 signaling, with AI therapy in postmenopausal women resulting in undetectable blood concentrations of E2 (140). Tamoxifen (TAM), a competitive inhibitor of ER, has also been linked with cognitive dysfunction when used to treat postmenopausal breast cancer (138), suggesting that memory deficits associated with AI may involve suppression of ER signaling. Indeed, the vast majority of studies that have compared the cognitive effects of $\mathrm{AI}$ and tamoxifen have concluded that they result in analogous cognitive disruptions $(27,139,141-$ 143), although one study reported enhanced disturbances with TAM (142). Another study showed no cognitive alterations with AI therapy, but that study also found no changes in circulating E2 (144). Unlike TAM therapy (143), AI are also associated with musculoskeletal problems, including joint pain and arthralgia. However, both treatments are associated with bone health impairments (145). AI therapy among breast cancer patients was most likely to cause forgetfulness, followed by difficulty concentrating, hair loss, and numbness/tingling of extremities (138). A meta-analyses of 911 breast cancer patients treated with various AI treatments or TAM compared to control women further revealed that those treated with AI or TAM showed similar verbal learning and memory impairments (146). Treatment of breast cancer patients with the AI, An, has also been associated with memory deficiencies, especially in verbal memory, mood disturbances, somnolence, anxiety, fatigue, and hot flashes in some studies (14, 147-149).

A few reports though have found no cognitive changes in women receiving long-term AI treatment. One study reporting no cognitive disruptions with women receiving transdermal $\mathrm{T}+$ AI therapy (Letro $2.5 \mathrm{mg}$ /day for at least 8 weeks) or placebo tablet also found no changes in circulating E2 (144). Similarly, an analysis with 111 women receiving $\mathrm{An}$ ( $1 \mathrm{mg} /$ day for 5 years) compared to 116 women receiving a placebo tablet revealed no effects of AI on mental function (150). Notwithstanding, the majority of studies suggest that there is cause for concern that women receiving AI treatment might demonstrate later learning and memory deficits. The few reports above that found null effect with AI therapy might be attributed to the measures used to examine cognitive ability, population of women examined (in that due to genetics or other factors some women might be less susceptible to AI-induced cognitive dysfunction), dose and type of AI administered, and various other potential confounders. If most women who receive AI show later neural effects, the question is what, if anything, can be done to mitigate this risk. One possibility that has received recent attention is to encourage physical activity in these patients $(151,152)$.

\section{POTENTIAL REMEDIATION STRATEGIES FOR AROMATASE INHIBITION-RELATED COGNITIVE IMPAIRMENTS}

An interesting observation is that many women taking AI report significantly less physical activity (153). The reduced motivation to engage in physical activity might be attributed to musculoskeletal problems (e.g., joint pain, arthralgia) following AI therapy; physical inactivity may also contribute to and/or exacerbate those musculoskeletal problems. Indeed, there is a relationship between women reporting adverse musculoskeletal symptoms and reduced physical activity (153). Associations between E2 synthesis and increased pain responses or nocioception have also been reported in rodents (154-157). AI-induced pain in mice can be blunted by treatment with an antagonist for the transient receptor potential Ankyrin 1 (TRPA1) channel (158). Moreover, this study showed that such pain responses are absent in $\operatorname{Trpa1}^{-/-}$mice (158). OVX rats administered a single dose of 1 or $5 \mathrm{mg} / \mathrm{kg}$ Letro had decreased mechanical withdrawal thresholds without changing thermal sensitivity, suggestive that central aromatase might guide the former response (159). Male rats repeatedly injected with $5 \mathrm{mg} / \mathrm{kg}$ Letro had mechanical, but not thermal, hypersensitivity that ceased when drug dosing was discontinued. A single dose of 
$5 \mathrm{mg} / \mathrm{kg}$ Letro or Exemestane to male rats enhanced flinching behavior induced by intraplantar injection of $1,000 \mathrm{nmol}$ of ATP. Within the dorsal root ganglia, both small and medium sized sensory neurons from Letro-treated rats were more excitable with increased action potential firing and lower resting membrane potential, which may augment nocioceptive behaviors in AI treated rats (159).

There is evidence in rodents that neuroE2, signaling through ESR1, increases physical activity (160). Moreover, estrous cycling in rodents robustly correlates with physical activity, with the peek estrus period associating with greatest physical activity (161). In fact, monitoring of female rodent physical activity is an accurate predictor of where they are in the estrous cycle. Interestingly, in humans, the suppressed willingness to engage in physical activity after AI therapy is not solely explained by musculoskeletal abnormalities (153), implying that loss of central E2 signaling may also explain part of the suppression of time spent exercising. Notably, the effect of aromatase inhibition on physical activity may be sex-specific since preclinical studies have shown that physical activity is not affected in male mice with aromatase suppression; however, this study did not assess female mice (162). Another experiment with rodents discovered that genetic ablation of aromatase resulted in increased adiposity in both males and females. They went on to show, in the females, that the increase in weight gain was due to reduced physical activity; however, they did not assess physical activity in the males (163). It may be the case that aromatase-mediated E2 increases physical activity in females whereas other factors (e.g., T) are more important regulators of physical activity in males. Human studies have also shown reduced physical activity specifically among women on AI (164). This finding likely has important clinical ramifications, as physical inactivity exacerbates musculoskeletal dysfunction, as mentioned above. Moreover, physical inactivity associates with poor cognition, whereas increasing physical activity improves learning and memory ability, as extensively reviewed (165). Mechanistically, physical activity enhances neurogenesis and synaptogenesis in the hippocampus, a region of the brain governing cognitive function in humans and rodents (165-168).

E2 enhances neurogenesis and synaptogenesis $(19,169,170)$, implying that E2 derived from aromatization of $\mathrm{T}$ in the brain of males may also have neuroprotective effects $(171,172)$. In contrast, AI treatment reduces hippocampal neurogenesis and synaptogenesis $(173,174)$. In isolated rat hippocampal neurons, Letro treatment reduces E2 synthesis with an accompanying decrease in density of spine synapses, presynaptic boutons, and decreased protein expression of the spine-marker, spinophilin (PPP1R9B) and the pre-synaptic marker, synaptophysin (SYP) $(173,174)$. Moreover, culture of hippocampal neurons reveals that Letro phosphorylates aromatase and reduces estradiol synthesis, whereas, treatment of cells with E2 results in phosphorylation of the enzyme and increased aromatase protein expression, suggesting estradiol synthesis in hippocampal neurons is subject to autocrine regulation (175).

It is thus reasonable to postulate that enhanced physical activity may be a critical adjuvant to AI therapy in humans, at least among women. Not only might it offset the musculoskeletal symptoms that occur commonly with use of AI, but it may also mitigate against the cognitive side effects of these drugs. Select animal data suggest that AI may adversely affect nocioceptive behaviors $(158,159)$. Similar findings have been reported in women treated with AI (176-178). One study assessing the effects of exercise to offset such symptoms associated with AI showed that exercise reduced pain sensitivity among women taking this therapy (179). It is unclear whether the CNS-specific changes with AI therapy may mediate the subjective musculoskeletal, cognitive, and nocioceptive responses in humans or animals, but both $\mathrm{AI}$ and exercise have been shown to directly induce brain changes. In humans, positron emission tomography (PET) scanning revealed significant impairments in metabolic activity in the medial temporal lobes in a group of women not reporting subjective symptoms of cognitive impairment; this may suggest that brain changes precede the detection of cognitive deficits and warrant treatments to prevent such brain changes from taking place while on AI therapy (13). Exercise may indeed be a lowcost and promising therapy to mitigate AI-induced cognitive disruptions and other neurobehavioral disorders (151, 152). A recent control trial study, termed Exercise Program in Cancer and Cognition (EPICC), has in fact been initiated to test this notion in that it will measure the effects of aerobic exercise on cognitive function in postmenopausal women with breast cancer and who are being treated with AI therapy (180).

\section{AROMATASE AND ALZHEIMER'S DISEASE}

This section will consider whether declining aromatase activity, especially within the brain, or genetic mutation/ablation of CYP19/Cyp19 in humans and rodents, respectively, is associated with an increased risk for $\mathrm{AD}$. Major findings of these studies are summarized in Tables 1, 2. One human study investigated associations between CYP19 gene polymorphisms with Alzheimer's disease (AD) (127). Those authors studied nine polymorphisms in $207 \mathrm{AD}$ patients, 23 cases of mild cognitive impairment, and 233 controls. These were all participants of the OPTIMA (196) study. The most salient finding from that study was that significant associations were found between variants of the aromatase gene and risk of $\mathrm{AD}$ specifically in women. Relatively similar results were reported in another cohort study representing 1,686 women participating as part of the Washington Heights Inwood Columbia Aging Project with six CYP19 single nucleotide polymorphisms (SNPs) present in women of predominantly Caucasian ancestry that are associated with increased risk of $\mathrm{AD}$ and 2 SNPs in this gene present in women of mixed and Hispanic origin linked are linked with decreased risk of AD (181). Several other studies have linked CYP19 genetic variants and interaction of this gene with other ones, including butyrylcholinesterase (BCHE), CYP17, and interleukin $10(I L-10)$ and susceptibility to developing AD (182-189). Taken together, these human studies support that an important relationship exists, in particular in females, between brain aromatase activity and normal cognitive function with genetic disruptions in this gene being associated with $\mathrm{AD}$ in older women. Depending on the location of the SNPs within the CYP19 
TABLE 1 | Human studies linking CYP19 gene polymorphisms and Alzheimer's disease (AD)*.

\begin{tabular}{lll}
\hline References & Study population and design & Major findings \\
\hline (127) & $\begin{array}{l}\text { Nine polymorphisms in in the CYP19 gene were examined in 207 } \\
\text { cases of AD, 23 cases of mild cognitive impairments (MCI), and }\end{array}$ & - Consistent findings were observed between AD and MCl cases. \\
$\begin{array}{l}233 \text { controls from the OPTIMA cohort that included men and } \\
\text { women. }\end{array}$ & $\begin{array}{l}\text { - Importantly, all associations with Cyp19 polymorphisms and AD were } \\
\text { identified entirely in women. }\end{array}$ \\
&
\end{tabular}

(181) SNPs in the CYP19 gene were examined in the 1686 women who participated in the Washington Heights Inwood Columbia Aging Project and correlated with their risk for AD.
- 6 SNPs associated with risk for ASD in Caucasian ancestry women.

- 2 SNPs were associated with decreased risk for this disorder in women of admixed/Hispanic ancestry.

- 2 SNPs were protective in women of predominantly African-based ancestry.
(182) Nine polymorphisms in in the CYP19 gene were examined in 394 AD patients and were compared to 469 control subjects, and haplotypes were identified using single-locus and haplotype approaches.
- 3 adjacent SNPs differed between AD and control groups.

- Both haplotype approaches identified an $\sim 60 \%$ increase in the risk for AD for one haploytype.

- Genetic variation in brain CYP19 may increase the risk for AD.
(183) Polymorphisms in the $5^{\prime}$-UTR of CYP19 and a non-K/K variant in the butyrilcholinesterase (BCHE) enzyme were examined in 187 sporadic AD patients and 172 control subjects in a Spanish population.
- The CYP19 C/C genotype was increased in AD patients also carrying the $\mathrm{BCHE}$ non-K allele relative to controls.

- Polymorphisms in CYP19 and BCHE may interact to affect risk for AD.
(184) 18 SNPs spanning the $5^{\prime}$ UTR region and the entire coding region of CYP19 was examined in 227 patients with $A D$ and 131 control spouses.

(185) Potential interactive effects of SNPs in CYP19 (5' UTR GG) and IL-10 (-1082, GG) genotypes were examined in 231 AD patients and 194 healthy controls.

(186) 3 SNPs (res12907866, rs17601241, and rs4646) in CYP19 were examined in 319 AD patients and 110 controls.
- A haplotype in block 1 and haplotype in block 2 increased the risk for developing the disease by 2 -fold in apolipoprotein $\mathrm{E}_{\varepsilon} 4\left(A P O E_{\varepsilon} 4\right)$ carriers.

- Subjects with the CYP19 (GG) and IL-10 (GG) genotypes showed a 6-fold risk reduction in developing $A D$ compared to individuals without these genotypes.

- While no linkage was fond in CYP19 SNPs and AD risk, genetic variation in this gene was associated with earlier onset of $A D$ age development in women, specifically the rs4636 genotypes carrying a T allele.

- This association was independent of a similar correlation found with the $A P O E_{\varepsilon} 4$ allele.

(187) SNPs in CYP17 and CYP19 were examined in 235 women with Down syndrome (DS), who ranged in age from 31 to 67 years and did not show any signs of dementia at the initial examination.
- 4 SNPs in CYP19 were correlated with 2-fold increase risk for AD with 3 only significant individuals without an $A P O E_{\varepsilon} 4$ allele.

- 4 SNPs in CYP17 were linked with a 2.5-fold increased risk for AD, which was independent of APOE genotype.

- Individuals carrying high risk alleles in both CYP17 and CYP19 were associated with $\sim 4$-fold elevated risk for $A D$ and increased sex hormone binding globulin in post-menopausal women.

- Variants in both genes involved in E2 bioavailability was associated with decreased age of $A D$ onset in women with $\mathrm{DS}$.
(188) SNPs in CYP19 and IL-10 were examined in 1757 AD patients and 6294 controls enrolled as part of the Epistasis Project.
- Women with SNP rs1065778 GG in the CYP19 gene was associated with increased odds ratio risk of developing AD.

- An interaction existed in women between IL-10 rs1800896 and CYP19A1 rs1062033 and increased risk for AD.

- Findings suggest that decreased serum E2 and neuroE2 may increase neuro-inflammation and risk for AD.
(189) SNPs in CYP19A1 were assessed in a Chinese Han population that included 207 patients with $A D$ and 256 control individuals.
- Within $A P O E_{\varepsilon} 4$ carriers, a different distribution of the $G$ allele and the $A G+$ GG genotype of CYP19A1 rs3751592 were found in AD patients compared to control individuals.

- No differences were identified in the distribution of CYP19A1 rs1065778 between $A D$ patients and controls, independent of $A P O E_{\varepsilon} 4$ genetic status. 
TABLE 2 | Rodent Model Studies Linking Cyp19/CYP19 gene and protein expression and AD-like signs*.

\begin{tabular}{|c|c|c|c|}
\hline References & Animal model & Treatment/dosing regimen & Major findings \\
\hline (190) & 5xFAD mouse model for $A D$ & None & $\begin{array}{l}\text { - Cyp } 19 \text { mRNA and protein expression lower in the } \\
\text { hippocampus in females but not males in 5xFAD mice. }\end{array}$ \\
\hline (191) & Male and Female 3xTgAD mice & $\begin{array}{l}\text { Some animals were gonadectomized and } \\
\text { others were left intact. Some of the } \\
\text { gonadectomized individuals were } \\
\text { implanted subcutaneously with hormone } \\
\text { treatment }(\mathrm{HT}) \text { over } 90 \text { days and were } \\
\text { replaced at } 6 \text { months of age, and } \\
\text { consisted of E2 }(0.25 \mathrm{mg}) \text { and } \\
\text { progesterone }(25 \mathrm{mg}) \text { or } 12.5 \mathrm{mg} \text { T for } \\
\text { females and males, respectively. } \\
\text { Within these above groups, some were } \\
\text { treated with An ( } 0.4 \mathrm{mg} / \text { animal/day). }\end{array}$ & 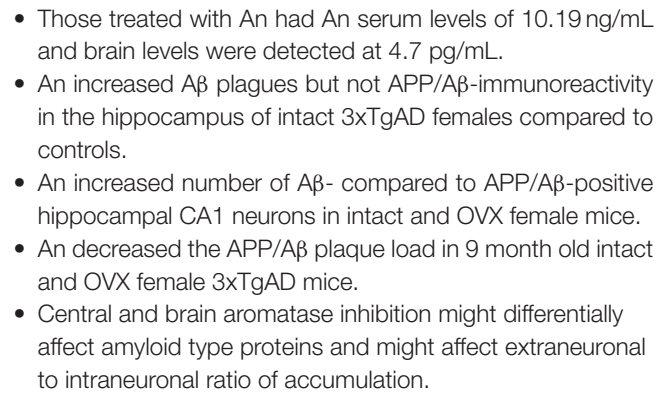 \\
\hline
\end{tabular}

\begin{tabular}{|c|c|c|c|}
\hline (192) & $\begin{array}{l}\text { Deletion of the FSR-receptor } \\
\text { (FORKO) and two transgenes with } \\
\text { one expressing the } \beta \text {-amyloid } \\
\text { precursor protein Swedish mutation } \\
\text { (APPsw) and the other expressing } \\
\text { presenilin-1 lacking exon } 9 \text { (PS1 } \Delta 9 \text { ) } \\
\text { and wild-type (WT) mice }\end{array}$ & $\begin{array}{l}\text { No treatment of transgenic mice. } \\
\text { Primary hippocampal neurons and glia } \\
\text { from } 5 \text {-day-old WT mouse pups were } \\
\text { cultured treated on day } 5 \text { with Letro }(1 \mu \mathrm{M}) \\
\text { or vehicle control for } 24 \mathrm{~h} \text {. }\end{array}$ & $\begin{array}{l}\text { - This mouse model has chronic E2 deficiency. } \\
\text { - the brains of these mice have marked hypertrophy of cortical } \\
\text { neurons and astrocytes and increased number of activated } \\
\text { microglial cells. } \\
\text { - A } \beta \text { plaques did not differ but such lesions appeared less } \\
\text { compact and larger than respective control mice. } \\
\text { - Letro treatment of cortical neural cultures from control mice } \\
\text { revealed similar glial abnormalities as identified in this AD } \\
\text { mouse model. }\end{array}$ \\
\hline (193) & $\begin{array}{l}\text { ArKO mice were bred to APP23 } \\
\text { transgenic mice to generate } \\
\text { E2-deficient APP23 mice }\end{array}$ & None & $\begin{array}{l}\text { - These trangenic mice demonstrate reduced brain E2 } \\
\text { concentrations, early-onset and increased brain production } \\
\text { and deposition of A } \beta \text { plaques. } \\
\text { - Microglial culture from these mice show impaired ability to } \\
\text { clear and degrade A } \beta \text { plaques. } \\
\text { - Such plaque abnormalities not found in OVX APP23 mice, } \\
\text { suggesting brain aromatase deficiency/estrogen depletion } \\
\text { as being an important determinant for developing } \\
\text { AD-associated neuropathologies. }\end{array}$ \\
\hline
\end{tabular}

\begin{tabular}{|c|c|c|}
\hline (194) & $\begin{array}{l}\text { APP23 female mice with genetic } \\
\text { deficiency of aromatase } \\
{[\operatorname{APP} / \operatorname{Ar}(+/-)]} \\
\text { OVX APP23 (APP/OVX) mice }\end{array}$ & $\begin{array}{l}3 \mathrm{months} \text { old, APP/OVX mice or } \\
\text { APP/Ar+/- female mice were implanted } \\
\text { subcutaneously with a E2 pellet ( } 1.7 \mathrm{mg} \text { or } \\
18.9 \mu \mathrm{g} / \text { day), a } 17 \alpha \text {-estradiol pellet } \\
(1.7 \mathrm{mg} \text { or } 18.9 \mu \mathrm{g} / \text { day), a genistein pellet } \\
(24 \mathrm{mg} \text { or } 26 \mu \mathrm{g} / \text { day), a black cohosh } \\
\text { pellet ( } 24 \mathrm{mg} \text { or } 26 \mu \mathrm{g} / \text { day), or placebo } \\
\text { pellet }\end{array}$ \\
\hline (195) & $\begin{array}{l}\text { Male mice generated from ArKO } \\
\text { combined with APP23 }\end{array}$ & None \\
\hline
\end{tabular}

- APP23 OVX mice contain estrogen in the brain.

- Only APP/Ar(+/-) but not APP23 OVX mice had reduced A $\beta$ plaques following $E 2$ or genistein $(G)$ treatment.

- E2 and G treatment to APP/Ar(+/-) resulted decreased BACE1 mRNA and protein expression.

- E2 or genistein supplementation might reduce AD neuropathological changes by increased neuroE2 concentrations.

- Male transgenic mice show reduced brain plague formation, improved cognitive functions, increased NEP activity, and reduced expression of BACE1.

- Findings suggest that in males an increase in endogenous $T$ due to removal of the CYP19 enzyme protects against AD.

- This protection might be due to increase T downregulation of BACE1 activity leading to decreased $\beta$-amyloid production and upregulation of NEP to enhance $\beta$-amyloid degradation.

*Meanings of abbreviations used in the Table are detailed in the manuscript.

gene, it might affect aromatase activity, substrate binding, and/or result in disequilibrium in this enzymatic pathway.

A handful of studies have examined aromatase expression in $\mathrm{AD}$ patients compared to controls. In three studies, lower aromatase mRNA or protein expression was identified in neurons of the hypothalamus, hippocampal, and basal brain regions (127, 197, 198). One study, however, found no difference in aromatase activity in the human frontal and temporal cortex in AD patients (199). Luchetti et al. (200) reported that in AD patients CYP19 mRNA expression was greater in the astrocytes 
within the prefrontal cortex region. Collectively, the studies suggest that aromatase expression, especially within the neurons of the hippocampal and basal region and glial cells, may serve as a reliable biomarker for $\mathrm{AD}$ patients.

Rodent models have also been useful in deciphering the roles of aromatase in $\mathrm{AD}$, as shown in Table 2. Studies showing that Cyp19 mRNA and protein expression are lower in the hippocampus in females but not males in a mouse model for AD (5xFAD) provide further evidence that normal expression of this enzyme in the brain is important in conferring against cognitive impairments and that females might be more vulnerable than males (190). To examine further the role of central and brain aromatase in $\mathrm{AD}$ mouse models, male and female were either gonadectomized or left intact, some of the gonadectomized individuals were treated with replacement hormone therapy, and other individuals were treated with An (additional details provided in Table 1) (191). Those treated with An had An serum levels of $10.19 \mathrm{ng} / \mathrm{mL}$ and brain levels were detected at $4.7 \mathrm{pg} / \mathrm{mL}$. An increase in $\mathrm{A} \beta$ plagues but not $\mathrm{APP} / \mathrm{A} \beta$-immunoreactivity was detected in the hippocampus of intact $3 \mathrm{xTgAD}$ females compared to controls. An increased number of $A \beta$ - compared to $\mathrm{APP} / \mathrm{A} \beta$-positive hippocampal CA1 neurons was identified in intact and OVX female mice, but this AI treatment decreased APP/A $\beta$ plaque load was identified in 9 month old intact and OVX female 3xTgAD mice. The findings suggest that central and brain aromatase inhibition might differentially affect amyloid type proteins and might affect extraneuronal to intraneuronal ratio of accumulation.

Other mouse models for $\mathrm{AD}$ also suggest that aromatase/E2 synthesis confers protection against neuropathological lesions. One such chimeric mouse has chronic E2 deficiency due to complete deletion of the FSR-receptor knockout (FORKO) and two transgenes with one expressing the $\beta$-amyloid precursor protein Swedish mutation (APPsw) and the other expressing presenilin-1 lacking exon 9 (PS1 $\Delta 9$ ), and the brains of these mice have marked hypertrophy of cortical neurons and astrocytes and increased number of activated microglial cells (192). While number of $\mathrm{A} \beta$ plaques did not differ, such lesions appeared less compact and larger than respective WT mice. Letro treatment of cortical neural cultures from control mice revealed similar glial abnormalities in this AD mouse model, further emphasizing the importance of aromatase and E2 synthesis in preventing such neural abnormalities associated with AD (192). To elucidate the role of aromatase/E2 synthesis in $\mathrm{AD}, \mathrm{ArKO}$ mice were paired with APP23 transgenic mice (another mouse model for AD) to generate E2-deficient APP23 mice (193). Such mice demonstrate reduced brain E2 concentrations, as well as earlyonset and increased brain production and deposition of $A \beta$ plaques. Microglial culture from E2-deficient APP23 mice show impaired ability to clear and degrade $A \beta$ plaques. Such plaque abnormalities were not found in OVX APP23 mice, implicating brain aromatase deficiency/E2 depletion as being an important determinant for developing $\mathrm{AD}$-associated neuropathologies. This study also showed postmortem analyses of brains from women with $\mathrm{AD}$ compared to those without this disease had lower levels of total and free E2, which was also reduced in the circulation. To determine whether E2 treatment might affect $\mathrm{AD}$ neuropathological changes in APP23 female mice with and without aromatase deficiency $(\operatorname{APP} / \operatorname{Ar}(+/-))$ and those lacking central E2 due to gonadetcomy (APP/OVX), both groups were provided estrogenic chemicals, e.g., ethinyl E2 or genistein (Details in Table 1) (194) These studies revealed that APP23 OVX mice contain E2 in the brain. Only APP/Ar(+/-) but not APP23 OVX mice had reduced $\mathrm{A} \beta$ plaques following $\mathrm{E} 2$ or genistein $(\mathrm{G})$ treatment. E2 and $\mathrm{G}$ treatment to $\mathrm{APP} / \mathrm{Ar}(+/-)$ resulted decreased betasecretase (BACE1) mRNA and protein expression. Results suggest that E2 or genistein supplementation might reduce $\mathrm{AD}$ neuropathological changes by increasing E2 concentrations in the brain.

A follow-up study by this same group revealed male mice generated from this same above cross (ArKO combined with APP23) have reduced brain plague formation, show improved cognitive functions, increased NEP activity (neprilysin, which mediates $A \beta$ clearance), and reduced expression of BACE1, suggesting in males an increase in endogenous $\mathrm{T}$ due to removal of the CYP19 enzyme protects against AD (195). This protection might be due to T-induced downregulation of BACE1 activity leading to decreased $\beta$-amyloid production and upregulation of NEP to enhance $\beta$-amyloid degradation (195).

\section{CONCLUSIONS AND FUTURE DIRECTIONS}

With the escalating usage of AI therapy to treat breast cancer and other clinical conditions, it is imperative to understand the potential effects such drugs can exert on the CNS. Aromatase conversion of $\mathrm{T}$ to $\mathrm{E} 2$ in the brain is integral at varying points in the lifespan. Early in development, this enzyme can help guide organizational programming of the brain $(27,28,107)$. Later in life, aromatase is needed for full manifestation of sexual behaviors in males, such as song production (111, 113-115). However, animal and human studies reveal that aromatase is also needed to support normal cognitive function and other behaviors in females (2, 19-22). Although the mechanisms are yet to be elucidated fully and may be multifactorial, it is clear that AI treatment can result in cognitive dysfunction in animals, as well as humans.

The neurobehavioral disturbances induced by AI likely depend upon when during the lifespan such drugs are administered. If during the perinatal period or the onset of sexual maturity, it could assumingly disrupt normal organizationalactivational programming, as shown in various animal models (201, 202). Post-menopausal women and older animals treated with such drugs are more likely to show memory deficits, increased pain response, and other emotional responses (10-18).

Avian and rodent models treated with AI have been useful in understanding and predicting the potential effects in patients treated with AI. However, effects can vary depending on the species tested, AI employed, and dose. In this aspect, ArKO mice that are systemically devoid of the aromatase enzyme might be a preferred animal model in attempting to understand the 

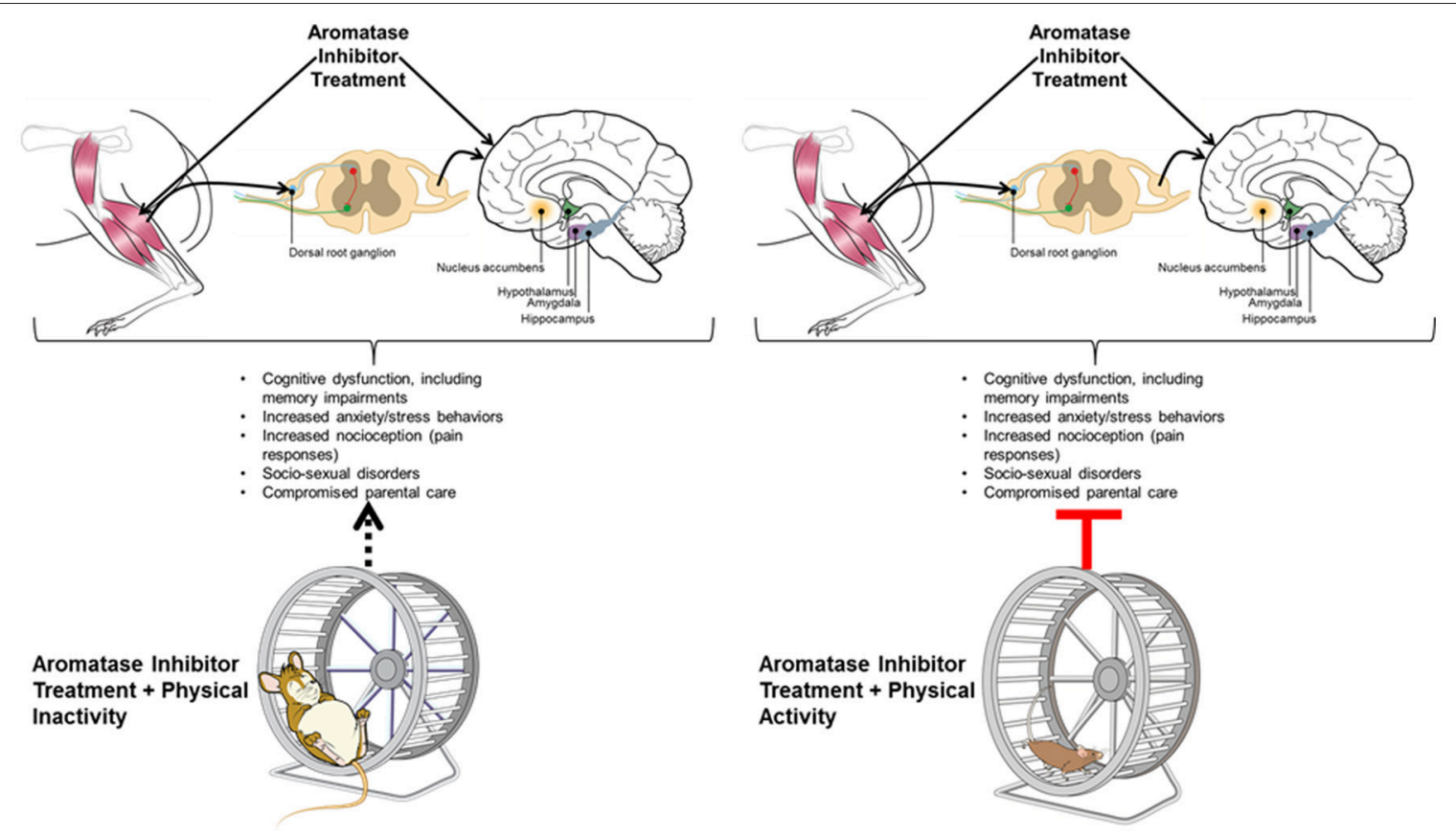

FIGURE 2 | Hypothetical model representing relationships between central and peripheral mechanisms leading to cognitive impairments associated with aromatase inhibition (Al) therapy, and suggesting physical activity as a potential remediation strategy for prevention of such effects. As shown on the reader's left-hand side of the figure, Al therapy is known to impair cognitive function, induce musculoskeletal symptoms, and is associated with suppressed voluntary physical activity in humans and animals. This constellation of symptoms may be related centrally, whereby Al adversely affects key brain regions (e.g., nucleus accumbens, as discussed in the Conclusions, this is the primary brain region associated with motivation for physical activity; hypothalamus and amygdala- as discussed in the Conclusions, these brain regions are linked with central metabolic and emotive control; hippocampus, associated with a variety of cognitive functions including learning and memory) which may lead to physical inactivity and contribute to or exacerbate Al-associated musculoskeletal effects. Similarly, Al-associated musculoskeletal effects, i.e., increased pain or nocioceptive responses, may further suppress motivation to engage in physical activity. As shown on the reader's right-hand side, increasing physical exercise, however, may enhance neurogenesis within all four of these brain regions (nucleus accumbens, hypothalamus, amygdala, and hippocampus), improve overall cognitive function, and lessen musculoskeletal/pain symptoms, thereby improving the main adverse symptoms associated with Al.

clinical sequelae of full suppression of aromatase. One potential limitation though with the current ArKO mouse models is that they lack the aromatase enzyme throughout their lifetime (2932). To pinpoint how ablation of aromatase at specific windows of time affects various neurobehavioral domains, a conditional knockout, especially one lacking this enzyme in different brain regions, is essential. Alternatively, adenovirus or other targeted approaches to delete aromatase expression in specific brain areas, such as the hippocampus and prefrontal cortex, that are required for long-term memory consolidation, can be employed. Such an adeno-associated viral vector approach has been used to silence Esr1 in the ventromedial (VMN) nuclei of the hypothalamus (203). A similar approach has been used to suppress Esr2 in the MPOA region from the prepubertal through adult period in male mice, which resulted in decreased aggressive but not sexual behaviors at adulthood (204). In contrast, pre-pubertal through adult suppression of Esr 2 in the MeA disrupted male preference for receptive females compared to non-receptive females. A follow-up study by this group revealed that knocking down Esr1 in the MeA or MPOA in intact male mice at 21 days of age resulted in reduced sexual and aggressive behaviors when administered into the MeA but only decreased sexual but not aggressive behaviors with MPOA treatment (205). Pre-pubertal suppression of $\mathrm{MeA}$ also resulted in reduced neurons within this brain region.

In rodents, the effects of AI might also depend upon sex, AI tested, and gonadal state of the individual. For instance, treatment of intact male rats with Letro seems to improve spatial working memory $(99,100)$. However, mixed results have been reported in females, which likely depend upon the AI tested, whether the animals are intact or OVX, and type of cognitive test (101-103).

Based on the majority of investigations reporting cognitive deficits in women receiving AI therapy, a big and openended question is whether these women are at greater risk for developing $\mathrm{AD}(134,136)$. Declining E2 levels at menopause renders women more susceptible to cognitive deficits and $\mathrm{AD}$, suggesting E2 replacement therapy might be beneficial in this aspect (206). Aromatase (CYP19) gene SNPs have been associated with increased or, for a few SNPs, decreased risk for AD (127, 181). In general, reductions in aromatase expression or activity are associated with $\mathrm{AD}$, especially in women $(127,197,198)$. A further protective role of brain aromatase is suggested by the fact that aromatase activity is elevated in astrocytes following brain injury (207). CYP19 mRNA expression is also elevated in astrocytes of the prefrontal cortex region in some $\mathrm{AD}$ patients 
(200). Rodent models for AD and those where such models have been combined with ones lacking Cyp19 gene provide robust support that normal expression of aromatase, especially within the neurons, is associated with less risk for AD-like cognitive impairments $(190,192,193)$, and that females might be more vulnerable than males (190). Investigatory studies examining whether women who received AI are more likely to develop AD are thus needed. If such is the case, it is important to consider strategies, such as physical activity, that can be implemented early on to reduce this risk. Given the importance of physical activity in combating many of the AI-linked neurobehavioral disruptions (151, 179), physicians should be actively encouraging women on AI therapy to engage in routine physical activity. Herein, we cite evidence pointing to a unified mechanism potentially linking physical activity to protection against cognitive and metabolic impairments often associated with AI therapy. Figure 2 summarizes mechanisms linking central and peripheral consequences of AI therapy. Future human, such as the recently initiated EPICC study (180), and rodent model studies are essential in understanding whether physical activity can mitigate $\mathrm{AI}$-induced CNS disorders and thereby improve memory

\section{REFERENCES}

1. Li R, Cui J, Shen Y. Brain sex matters: estrogen in cognition and Alzheimer's disease. Mol Cell Endocrinol. (2014) 389:13-21. doi: 10.1016/j.mce.2013.12.018

2. Hara Y, Waters EM, McEwen BS, Morrison JH. Estrogen effects on cognitive and synaptic health over the lifecourse. Physiol Rev. (2015) 95:785-807. doi: 10.1152/physrev.00036.2014

3. Abu Hashim H. Potential role of aromatase inhibitors in the treatment of endometriosis. Int $J$ Womens Health (2014) 6:671-80. doi: 10.2147/IJWH.S34684

4. Franik S, Kremer JA, Nelen WL, Farquhar C. Aromatase inhibitors for subfertile women with polycystic ovary syndrome. Cochrane Database Syst Rev (2014). Cd010287. doi: 10.1002/14651858.CD010287.pub2

5. Klement AH, Casper RF. The use of aromatase inhibitors for ovulation induction. Curr Opin Obstet Gynecol. (2015) 27:206-9. doi: 10.1097/GCO.0000000000000163

6. Roque M, Tostes AC, Valle M, Sampaio M, Geber S. Letrozole versus clomiphene citrate in polycystic ovary syndrome: systematic review and meta-analysis. Gynecol Endocrinol. (2015) 31:917-21. doi: 10.3109/09513590.2015.1096337

7. Adhikari N, Amin SA, Saha A, Jha T. Combating breast cancer with non-steroidal aromatase inhibitors (NSAIs): Understanding the chemico-biological interactions through comparative SAR/QSAR study. Eur J Med Chem. (2017) 137:365-438. doi: 10.1016/j.ejmech.2017. 05.041

8. Daldorff S, Mathiesen RM, Yri OE, Odegard HP, Geisler J. Cotargeting of CYP-19 (aromatase) and emerging, pivotal signalling pathways in metastatic breast cancer. Br J Cancer (2017) 116:10-20. doi: 10.1038/bjc.2016.405

9. Goldvaser H, Algorashi I, Ribnikar D, Seruga B, Templeton AJ, Ocana A, et al. Efficacy of extended adjuvant therapy with aromatase inhibitors in early breast cancer among common clinicopathologically-defined subgroups: a systematic review and meta-analysis. Cancer Treat Rev. (2017) 60:53-9. doi: 10.1016/j.ctrv.2017.08.008

10. Agrawal K, Onami S, Mortimer JE, Pal SK. Cognitive changes associated with endocrine therapy for breast cancer. Maturitas (2010) 67:209-14. doi: 10.1016/j.maturitas.2010.07.004

11. Bian C, Zhao Y, Guo Q, Xiong Y, Cai W, Zhang J. Aromatase inhibitor letrozole downregulates steroid receptor coactivator-1 in specific brain regions that primarily related to memory, neuroendocrine impairments and other clinical signs in women receiving such therapies.

From being diagnosed to treated, women with breast cancer have already endured an enormous emotional toll. It is thus essential that we understand why such women who receive AI are more likely to experience memory deficits, increased pain responses, and other CNS and musculoskeletal affects. This will allow for the development of strategies to alleviate such negative side effects, thus allowing women to recover fully from both a physical and mental health standpoint. Exercise, both during the time of receiving such drugs and after, appears to hold the key in maintaining normal cognitive function in these women and the potential beneficial mechanisms of physical activity should be tested in animal models treated with AI or transgenic mice lacking aromatase enzyme at certain time points and/or brain regions.

\section{AUTHOR CONTRIBUTIONS}

CR, DS, and VV-P researched this area and drafted and revised the manuscript. and integration. J Steroid Biochem Mol Biol. (2014) 141:37-43. doi: 10.1016/j.jsbmb.2013.12.020

12. Frank JS, Vance DE, Jukkala A, Meneses KM. Attention and memory deficits in breast cancer survivors: implications for nursing practice and research. $J$ Neurosci Nurs. (2014) 46:274-84. doi: 10.1097/JNN.0000000000000078

13. Hurria A, Patel SK, Mortimer J, Luu T, Somlo G, Katheria V, et al. The effect of aromatase inhibition on the cognitive function of older patients with breast cancer. Clin Breast Cancer (2014) 14:132-40. doi: 10.1016/j.clbc.2013.10.010

14. Bender CM, Merriman JD, Gentry AL, Ahrendt GM, Berga SL, Brufsky $\mathrm{AM}$, et al. Patterns of change in cognitive function with anastrozole therapy. Cancer (2015) 121:2627-36. doi: 10.1002/cncr.29393

15. Karatas F, Akin S, Babacan T, Sever AR, Altundag K. Can aromatase inhibitors cause forgetfulness in women with breast cancer? J BUON (2015) 20:935.

16. Beckwee D, Leysen L, Meuwis K, Adriaenssens N. Prevalence of aromatase inhibitor-induced arthralgia in breast cancer: a systematic review and meta-analysis. Support Care Cancer (2017) 25:1673-86. doi: $10.1007 / \mathrm{s} 00520-017-3613-\mathrm{z}$

17. Chan A, De Boer R, Gan A, Willsher P, Martin R, Zissiadis Y, et al. Randomized phase II placebo-controlled study to evaluate the efficacy of topical pure emu oil for joint pain related to adjuvant aromatase inhibitor use in postmenopausal women with early breast cancer: JUST (Joints Under Study). Support Care Cancer (2017) 25:3785-91. doi: 10.1007/s00520-017-3810-9

18. Fontein DB, Charehbili A, Nortier JW, Putter H, Kranenbarg EM, Kroep JR, et al. Specific adverse events are associated with response to exemestane therapy in postmenopausal breast cancer patients: results from the TEAMIIA study (BOOG2006-04). Eur J Surg Oncol. (2017) 43:619-24. doi: 10.1016/j.ejso.2016.07.146

19. Duarte-Guterman P, Yagi S, Chow C, Galea LA. Hippocampal learning, memory, and neurogenesis: effects of sex and estrogens across the lifespan in adults. Horm Behav. (2015) 74:37-52. doi: 10.1016/j.yhbeh.2015.05.024

20. Newhouse P, Dumas J. Estrogen-cholinergic interactions: implications for cognitive aging. Horm Behav. (2015) 74:173-85. doi: 10.1016/j.yhbeh.2015.06.022

21. Ycaza Herrera A, Mather M. Actions and interactions of estradiol and glucocorticoids in cognition and the brain: implications for aging women. Neurosci Biobehav Rev. (2015) 55:36-52. doi: 10.1016/j.neubiorev.2015.04.005 
22. Engler-Chiurazzi EB, Brown CM, Povroznik JM, Simpkins JW. Estrogens as neuroprotectants: estrogenic actions in the context of cognitive aging and brain injury. Prog Neurobiol. (2016) 157:188-211. doi: 10.1016/j.pneurobio.2015.12.008

23. Watson J, Adkins-Regan E. Activation of sexual behavior by implantation of testosterone propionate and estradiol benzoate into the preoptic area of the male Japanese quail (Coturnix japonica). Horm Behav. (1989) 23:251-68. doi: 10.1016/0018-506X(89)90065-2

24. Watson J, Adkins-Regan E. Testosterone implanted in the preoptic area of male Japanese quail must be aromatized to activate copulation. Horm Behav. (1989) 23:432-47. doi: 10.1016/0018-506X(89)90055-X

25. Bowers JM, Waddell J, McCarthy MM. A developmental sex difference in hippocampal neurogenesis is mediated by endogenous oestradiol. Biol Sex Differ. (2010) 1:8. doi: 10.1186/2042-6410-1-8

26. Konkle AT, McCarthy MM. Developmental time course of estradiol, testosterone, and dihydrotestosterone levels in discrete regions of male and female rat brain. Endocrinology (2011) 152:223-35. doi: 10.1210/en.2010-0607

27. Arnold AP, Breedlove SM. Organizational and activational effects of sex steroids on brain and behavior: a reanalysis. Horm Behav. (1985) 19:469-98. doi: 10.1016/0018-506X(85)90042-X

28. Morris JA, Jordan CL, Breedlove SM. Sexual differentiation of the vertebrate nervous system. Nat Neurosci. (2004) 7:1034-9. doi: 10.1038/nn1325

29. Fisher CR, Graves KH, Parlow AF, Simpson ER. Characterization of mice deficient in aromatase (ArKO) because of targeted disruption of the cyp19 gene. Proc Natl Acad Sci USA. (1998) 95:6965-70. doi: $10.1073 /$ pnas.95.12.6965

30. Nemoto Y, Toda K, Ono M, Fujikawa-Adachi K, Saibara T, Onishi S, et al. Altered expression of fatty acid-metabolizing enzymes in aromatasedeficient mice. J Clin Invest. (2000) 105:1819-25. doi: 10.1172/JCI9575

31. Toda K, Takeda K, Okada T, Akira S, Saibara T, Kaname T, et al. Targeted disruption of the aromatase P450 gene (Cyp19) in mice and their ovarian and uterine responses to 17beta-oestradiol. J Endocrinol. (2001) 170:99-111. doi: 10.1677/joe.0.1700099

32. Hill RA, Boon WC. Estrogens, brain, and behavior: lessons from knockout mouse models. Semin Reprod Med. (2009) 27:218-28. doi: 10.1055/s-0029-1216275

33. Daniel JM. Estrogens, estrogen receptors, and female cognitive aging: the impact of timing. Horm Behav. (2013) 63:231-7. doi: 10.1016/j.yhbeh.2012.05.003

34. Korol DL, Pisani SL. Estrogens and cognition: friends or foes? An evaluation of the opposing effects of estrogens on learning and memory. Horm Behav. (2015) 74:105-15. doi: 10.1016/j.yhbeh.2015.06.017

35. Cornil CA. On the role of brain aromatase in females: why are estrogens produced locally when they are available systemically? J Comp Physiol A Neuroethol Sens Neural Behav Physiol. (2018) 204:31-49. doi: 10.1007/s00359-017-1224-2

36. Naftolin F, Ryan KJ, Petro Z. Aromatization of androstenedione by limbic system tissue from human foetuses. J Endocrinol. (1971) 51:795-6. doi: 10.1677/joe.0.0510795

37. Baum MJ, Vreeburg JT. Copulation in castrated male rats following combined treatment with estradiol and dihydrotestosterone. Science (1973) 182:283-5. doi: 10.1126/science.182.4109.283

38. Larsson K, Sodersten P, Beyer C. Induction of male sexual behaviour by oestradiol benzoate in combination with dihydrotestosterone. J Endocrinol. (1973) 57:563-4. doi: 10.1677/joe.0.0570563

39. Lauber ME, Lichtensteiger W. Pre- and postnatal ontogeny of aromatase cytochrome P450 messenger ribonucleic acid expression in the male rat brain studied by in situ hybridization. Endocrinology (1994) 135:1661-8. doi: 10.1210/endo.135.4.7925130

40. Foidart A, Reid J, Absil P, Yoshimura N, Harada N, Balthazart J. Critical reexamination of the distribution of aromatase-immunoreactive cells in the quail forebrain using antibodies raised against human placental aromatase and against the recombinant quail, mouse or human enzyme. J Chem Neuroanat. (1995) 8:267-82. doi: 10.1016/0891-0618(95)00054-B

41. Wagner CK, Morrell JI. Distribution and steroid hormone regulation of aromatase mRNA expression in the forebrain of adult male and female rats: a cellular-level analysis using in situ hybridization. J Comp Neurol.
(1996) 370:71-84. doi: 10.1002/(SICI)1096-9861(19960617)370:1<71::AIDCNE7>3.0.CO;2-I

42. Roselli CE, Stormshak F, Resko JA. Distribution and regulation of aromatase activity in the ram hypothalamus and amygdala. Brain Res. (1998) 811:10510. doi: 10.1016/S0006-8993(98)00995-0

43. Saldanha CJ, Tuerk MJ, Kim YH, Fernandes AO, Arnold AP, Schlinger BA. Distribution and regulation of telencephalic aromatase expression in the zebra finch revealed with a specific antibody. J Comp Neurol. (2000) 423:619-30. doi: 10.1002/1096-9861(20000807)423:4<619::AID-CNE7>3.0. $\mathrm{CO} ; 2-\mathrm{U}$

44. Roselli CE, Klosterman S, Resko JA. Anatomic relationships between aromatase and androgen receptor mRNA expression in the hypothalamus and amygdala of adult male cynomolgus monkeys. J Comp Neurol. (2001) 439:208-23. doi: 10.1002/cne.1343

45. Roselli CE, Liu M, Hurn PD. Brain aromatization: classic roles and new perspectives. Semin Reprod Med. (2009) 27:207-17. doi: 10.1055/s-0029-1216274

46. Cisternas CD, Tome K, Caeiro XE, Dadam FM, Garcia-Segura LM, Cambiasso MJ. Sex chromosome complement determines sex differences in aromatase expression and regulation in the stria terminalis and anterior amygdala of the developing mouse brain. Mol Cell Endocrinol. (2015) 414:99-110. doi: 10.1016/j.mce.2015.07.027

47. Balthazart J, Foidart A, Surlemont C, Harada N. Neuroanatomical specificity in the co-localization of aromatase and estrogen receptors. J Neurobiol. (1991) 22:143-57. doi: 10.1002/neu.480220205

48. Veney SL, Rissman EF. Co-localization of estrogen receptor and aromatase enzyme immunoreactivities in adult musk shrew brain. Horm Behav. (1998) 33:151-62. doi: 10.1006/hbeh.1998.1446

49. Roselli CE, Resko JA. Aromatase activity in the rat brain: hormonal regulation and sex differences. J Steroid Biochem Mol Biol. (1993) 44:499-508. doi: 10.1016/0960-0760(93)90254-T

50. Roselli CE, Resko JA. Sex differences in androgen-regulated expression of cytochrome P450 aromatase in the rat brain. J Steroid Biochem Mol Biol. (1997) 61:365-74. doi: 10.1016/S0960-0760(97)80034-9

51. Boon WC, Chow JD, Simpson ER. The multiple roles of estrogens and the enzyme aromatase. Prog Brain Res. (2010) 181:209-32. doi: 10.1016/S0079-6123(08)81012-6

52. Konkle AT, Balthazart J. Sex differences in the rapid control of aromatase activity in the quail preoptic area. J Neuroendocrinol. (2011) 23:424-34. doi: 10.1111/j.1365-2826.2011.02121.x

53. Balthazart J, Tlemcani O, Harada N. Localization of testosteronesensitive and sexually dimorphic aromatase-immunoreactive cells in the quail preoptic area. J Chem Neuroanat. (1996) 11:147-71. doi: 10.1016/0891-0618(96)00149-4

54. Voigt C, Ball GF, Balthazart J. Neuroanatomical specificity of sex differences in expression of aromatase mRNA in the quail brain. J Chem Neuroanat. (2007) 33:75-86. doi: 10.1016/j.jchemneu.2006.12.004

55. Peterson RS, Yarram L, Schlinger BA, Saldanha CJ. Aromatase is pre-synaptic and sexually dimorphic in the adult zebra finch brain. Proc Biol Sci. (2005) 272:2089-96. doi: 10.1098/rspb.2005.3181

56. Rohmann KN, Schlinger BA, Saldanha CJ. Subcellular compartmentalization of aromatase is sexually dimorphic in the adult zebra finch brain. Dev Neurobiol. (2007) 67:1-9. doi: 10.1002/dneu.20303

57. Abdelgadir SE, Roselli CE, Choate JV, Resko JA. Distribution of aromatase cytochrome P450 messenger ribonucleic acid in adult rhesus monkey brains. Biol Reprod. (1997) 57:772-7. doi: 10.1095/biolreprod 57.4.772

58. Dickens MJ, Balthazart J, Cornil CA. Brain aromatase and circulating corticosterone are rapidly regulated by combined acute stress and sexual interaction in a sex-specific manner. J Neuroendocrinol. (2012) 24:1322-34. doi: 10.1111/j.1365-2826.2012.02340.x

59. Kadioglu P, Oral G, Sayitoglu M, Erensoy N, Senel B, Gazioglu N, et al. Aromatase cytochrome $\mathrm{P} 450$ enzyme expression in human pituitary. Pituitary (2008) 11:29-35. doi: 10.1007/s11102-0070065-3

60. Sasano H, Takashashi K, Satoh F, Nagura H, Harada N. Aromatase in the human central nervous system. Clin Endocrinol. (1998) 48:325-9. doi: 10.1046/j.1365-2265.1998.00390.x 
61. Roselli CE, Horton LE, Resko JA. Time-course and steroid specificity of aromatase induction in rat hypothalamus-preoptic area. Biol Reprod. (1987) 37:628-33. doi: 10.1095/biolreprod37.3.628

62. Balthazart J, Foidart A, Hendrick JC. The induction by testosterone of aromatase activity in the preoptic area and activation of copulatory behavior. Physiol Behav. (1990) 47:83-94. doi: 10.1016/0031-9384(90)90045-6

63. Balthazart J, Schumacher M, Evrard L. Sex differences and steroid control of testosterone-metabolizing enzyme activity in the quail brain. J Neuroendocrinol. (1990) 2:675-83. doi: 10.1111/j.1365-2826.1990.tb 00464.x

64. Tabatadze N, Sato SM, Woolley CS. Quantitative analysis of long-form aromatase mRNA in the male and female rat brain. PLoS ONE (2014) 9:e100628. doi: 10.1371/journal.pone.0100628

65. Schumacher M, Balthazart J. Testosterone-induced brain aromatase is sexually dimorphic. Brain Res. (1986) 370:285-93. doi: 10.1016/0006-8993(86)90483-X

66. Balthazart J, Foidart A, Harada N. Immunocytochemical localization of aromatase in the brain. Brain Res. (1990) 514:327-33. doi: 10.1016/0006-8993(90)91428-J

67. Steimer T, Hutchison JB. Is androgen-dependent aromatase activity sexually differentiated in the rat and dove preoptic area? J Neurobiol. (1990) 21:78795. doi: 10.1002/neu.480210512

68. Hutchison RE, Wozniak AW, Hutchison JB. Regulation of female brain aromatase activity during the reproductive cycle of the dove. J Endocrinol. (1992) 134:385-96. doi: 10.1677/joe.0.1340385

69. Roselli CE, Abdelgadir SE, Jorgensen E, Resko JA. Sex differences in androgen-regulated cytochrome P450 aromatase mRNA in the rat brain. Endocrine (1996) 5:59-65. doi: 10.1007/BF02738657

70. Roselli CE, Klosterman SA, Fasasi TA. Sex differences in androgen responsiveness in the rat brain: regional differences in the induction of aromatase activity. Neuroendocrinology (1996) 64:139-45. doi: $10.1159 / 000127111$

71. Roselli CE, Klosterman SA. Sexual differentiation of aromatase activity in the rat brain: effects of perinatal steroid exposure. Endocrinology (1998) 139:3193-201. doi: 10.1210/endo.139.7.6101

72. Voigt C, Ball GF, Balthazart J. Effects of sex steroids on aromatase mRNA expression in the male and female quail brain. Gen Comp Endocrinol. (2011) 170:180-8. doi: 10.1016/j.ygcen.2010.10.003

73. Balthazart J, Baillien M, Ball GF. Phosphorylation processes mediate rapid changes of brain aromatase activity. J Steroid Biochem Mol Biol. (2001) 79:261-77. doi: 10.1016/S0960-0760(01)00143-1

74. Balthazart J, Baillien M, Charlier TD, Cornil CA, Ball GF. Multiple mechanisms control brain aromatase activity at the genomic and non-genomic level. J Steroid Biochem Mol Biol. (2003) 86:367-79. doi: 10.1016/S0960-0760(03)00346-7

75. Hojo Y, Hattori TA, Enami T, Furukawa A, Suzuki K, Ishii HT, et al. Adult male rat hippocampus synthesizes estradiol from pregnenolone by cytochromes P45017alpha and P450 aromatase localized in neurons. Proc Natl Acad Sci USA. (2004) 101:865-70. doi: 10.1073/pnas.2630225100

76. Balthazart J, Baillien M, Ball GF. Rapid control of brain aromatase activity by glutamatergic inputs. Endocrinology (2006) 147:359-66. doi: 10.1210/en.2005-0845

77. Remage-Healey L, Maidment NT, Schlinger BA. Forebrain steroid levels fluctuate rapidly during social interactions. Nat Neurosci. (2008) 11:1327-34. doi: 10.1038/nn.2200

78. Balthazart J, Charlier TD, Cornil CA, Dickens MJ, Harada N, Konkle AT, et al. Sex differences in brain aromatase activity: genomic and nongenomic controls. Front Endocrinol. (2011) 2:34. doi: 10.3389/fendo.2011. 00034

79. Charlier TD, Harada N, Balthazart J, Cornil CA. Human and quail aromatase activity is rapidly and reversibly inhibited by phosphorylating conditions. Endocrinology (2011) 152:4199-210. doi: 10.1210/en.2011-0119

80. Remage-Healey L, Dong S, Maidment NT, Schlinger BA. Presynaptic control of rapid estrogen fluctuations in the songbird auditory forebrain. J Neurosci. (2011) 31:10034-8. doi: 10.1523/JNEUROSCI.0566-11.2011

81. Charlier TD, Cornil CA, Balthazart J. Rapid modulation of aromatase activity in the vertebrate brain. J Exp Neurosci. (2013) 7:31-7. doi: $10.4137 /$ JEN.S11268
82. Sato SM, Woolley CS. Acute inhibition of neurosteroid estrogen synthesis suppresses status epilepticus in an animal model. Elife (2016) 5:e12917. doi: 10.7554/eLife.12917

83. Gerlai R. Behavioral tests of hippocampal function: simple paradigms complex problems. Behav Brain Res. (2001) 125:269-77. doi: 10.1016/S0166-4328(01)00296-0

84. Terry AV Jr. Chapter 13: Spatial navigation (water maze) tasks. In: Methods of Behavior Analysis in Neuroscience. Buccafusco JJ, editor. Boca Raton, FL: CRC Press; Taylor and Francis Taylor; Francis Group, LLC. (2009).

85. Vorhees CV, Williams MT. Value of water mazes for assessing spatial and egocentric learning and memory in rodent basic research and regulatory studies. Neurotoxicol Teratol. (2014) 45:75-90. doi: 10.1016/j.ntt.2014.07.003

86. Arakawa H, Iguchi Y. Ethological and multi-behavioral analysis of learning and memory performance in laboratory rodent models. Neurosci Res. (2018) 135:1-12. doi: 10.1016/j.neures.2018.02.001

87. Martin S, Jones M, Simpson E, Van Den Buuse M. Impaired spatial reference memory in aromatase-deficient (ArKO) mice. Neuroreport (2003) 14:197982. doi: 10.1097/00001756-200310270-00020

88. Boon WC, Diepstraten J, Van Der Burg J, Jones ME, Simpson ER, Van Den Buuse M. Hippocampal NMDA receptor subunit expression and watermaze learning in estrogen deficient female mice. Brain Res Mol Brain Res. (2005) 140:127-32. doi: 10.1016/j.molbrainres.2005.07.004

89. Rosenfeld CS, Ferguson SA. Barnes maze testing strategies with small and large rodent models. J Vis Exp. (2014) 84:e51194. doi: 10.3791/51194

90. Galea LA, Kavaliers M, Ossenkopp KP. Sexually dimorphic spatial learning in meadow voles Microtus pennsylvanicus and deer mice Peromyscus maniculatus. J Exp Biol. (1996) 199:195-200.

91. Jasarevic E, Sieli PT, Twellman EE, Welsh TH Jr, Schachtman TR, Roberts $\mathrm{RM}$, et al. Disruption of adult expression of sexually selected traits by developmental exposure to bisphenol A. Proc Natl Acad Sci USA. (2011) 108:11715-20. doi: 10.1073/pnas.1107958108

92. Jasarevic E, Williams SA, Vandas GM, Ellersieck MR, Liao C, Kannan K, et al. Sex and dose-dependent effects of developmental exposure to bisphenol A on anxiety and spatial learning in deer mice (Peromyscus maniculatus bairdii) offspring. Horm Behav. (2013) 63:180-9. doi: 10.1016/j.yhbeh.2012.09.009

93. Pierman S, Sica M, Allieri F, Viglietti-Panzica C, Panzica GC, Bakker J. Activational effects of estradiol and dihydrotestosterone on social recognition and the arginine-vasopressin immunoreactive system in male mice lacking a functional aromatase gene. Horm Behav. (2008) 54:98-106. doi: 10.1016/j.yhbeh.2008.02.001

94. Wesson DW, Keller M, Douhard Q, Baum MJ, Bakker J. Enhanced urinary odor discrimination in female aromatase knockout (ArKO) mice. Horm Behav. (2006) 49:580-6. doi: 10.1016/j.yhbeh.2005.12.013

95. Brus M, Trouillet AC, Hellier V, Bakker J. Estradiol-induced neurogenesis in the female accessory olfactory bulb is required for the learning of the male odor. J Neurochem. (2016) 138:457-68. doi: 10.1111/jnc.13677

96. Zhou L, Fester L, Haghshenas S, De Vrese X, Von Hacht R, Gloger S, et al. Oestradiol-induced synapse formation in the female hippocampus: roles of oestrogen receptor subtypes. J Neuroendocrinol. (2014) 26:439-47. doi: 10.1111/jne.12162

97. Bakker J, Baum MJ, Slob AK. Neonatal inhibition of brain estrogen synthesis alters adult neural Fos responses to mating and pheromonal stimulation in the male rat. Neuroscience (1996) 74:251-60. doi: 10.1016/0306-4522(96)00096-6

98. Taylor GT, Manzella FM, Huffman J, Cabrera OH, Hoffman J. Cognition in female rats after blocking conversion of androgens to estrogens. Horm Behav. (2017) 90:84-9. doi: 10.1016/j.yhbeh.2017.02.011

99. Alejandre-Gomez M, Garcia-Segura LM, Gonzalez-Burgos I. Administration of an inhibitor of estrogen biosynthesis facilitates working memory acquisition in male rats. Neurosci Res. (2007) 58:272-7. doi: 10.1016/j.neures.2007.03.011

100. Moradpour F, Naghdi N, Fathollahi Y. Anastrozole improved testosteroneinduced impairment acquisition of spatial learning and memory in the hippocampal CA1 region in adult male rats. Behav Brain Res. (2006) 175:22332. doi: 10.1016/j.bbr.2006.08.037

101. Zameer S, Vohora D. Effect of aromatase inhibitors on learning and memory and modulation of hippocampal dickkopf-1 and sclerostin in female mice. Pharmacol Rep. (2017) 69:1300-7. doi: 10.1016/j.pharep.2017.06.002 
102. Meng FT, Ni RJ, Zhang Z, Zhao J, Liu YJ, Zhou JN. Inhibition of oestrogen biosynthesis induces mild anxiety in C57BL/6J ovariectomized female mice. Neurosci Bull. (2011) 27:241-50. doi: 10.1007/s12264-011-1014-8

103. Mennenga SE, Koebele SV, Mousa AA, Alderete TJ, Tsang CW, Acosta JI, et al. Pharmacological blockade of the aromatase enzyme, but not the androgen receptor, reverses androstenedione-induced cognitive impairments in young surgically menopausal rats. Steroids (2015) 99:16-25. doi: 10.1016/j.steroids.2014.08.010

104. Liu M, Huangfu X, Zhao Y, Zhang D, Zhang J. Steroid receptor coactivator-1 mediates letrozole induced downregulation of postsynaptic protein PSD-95 in the hippocampus of adult female rats. J Steroid Biochem Mol Biol. (2015) 154:168-75. doi: 10.1016/j.jsbmb.2015.07.011

105. Tuscher JJ, Szinte JS, Starrett JR, Krentzel AA, Fortress AM, Remage-Healey $\mathrm{L}$, et al. Inhibition of local estrogen synthesis in the hippocampus impairs hippocampal memory consolidation in ovariectomized female mice. Horm Behav. (2016) 83:60-7. doi: 10.1016/j.yhbeh.2016.05.001

106. Nelson BS, Black KL, Daniel JM. Circulating Estradiol Regulates Brainderived estradiol via actions at $\mathrm{GnRH}$ receptors to impact memory in ovariectomized rats. eNeuro (2016) 3. doi: 10.1523/ENEURO.0321-16.2016

107. Phoenix $\mathrm{CH}$, Goy RW, Gerall AA, Young WC. Organizing action of prenatally administered testosterone propionate on the tissues mediating mating behavior in the female guinea pig. Endocrinology (1959) 65:369-82. doi: 10.1210/endo-65-3-369

108. Remage-Healey L, Dong SM, Chao A, Schlinger BA. Sex-specific, rapid neuroestrogen fluctuations and neurophysiological actions in the songbird auditory forebrain. J Neurophysiol. (2012) 107:1621-31. doi: 10.1152/jn.00749.2011

109. Bailey DJ, Saldanha CJ. The importance of neural aromatization in the acquisition, recall, and integration of song and spatial memories in passerines. Horm Behav. (2015) 74:116-24. doi: 10.1016/j.yhbeh.2015.06.007

110. Comito D, Pradhan DS, Karleen BJ, Schlinger BA. Region-specific rapid regulation of aromatase activity in zebra finch brain. eNeuro (2015) 136:1177-85. doi: 10.1111/jnc.13513

111. De Groof G, Balthazart J. Topography and lateralized effect of acute aromatase inhibition on auditory processing in a seasonal songbird. $J$ Neurosci. (2017) 37:4243-4254. doi: 10.1523/JNEUROSCI.1961-16.2017

112. Vahaba DM, Macedo-Lima M. Sensory coding and sensitivity to local estrogens shift during critical period milestones in the auditory cortex of male songbirds. eNeuro (2017) 4. doi: 10.1523/ENEURO.031717.2017

113. Yoder KM, Lu K, Vicario DS. Blocking estradiol synthesis affects memory for songs in auditory forebrain of male zebra finches. Neuroreport (2012) 23:922-6. doi: 10.1097/WNR.0b013e3283588b61

114. Calisi RM, Knudsen DP, Krause JS, Wingfield JC, Gentner TQ. Estradiol differentially affects auditory recognition and learning according to photoperiodic state in the adult male songbird, European starling (Sturnus vulgaris). PeerJ (2013) 1:e150. doi: 10.7717/peerj.150

115. Alward BA, De Bournonville C, Chan TT, Balthazart J, Cornil CA, Ball GF. Aromatase inhibition rapidly affects in a reversible manner distinct features of birdsong. Sci Rep. (2016) 6:32344. doi: 10.1038/srep32344

116. Fusani L, Metzdorf R, Hutchison JB, Gahr M. Aromatase inhibition affects testosterone-induced masculinization of song and the neural song system in female canaries. J Neurobiol. (2003) 54:370-9. doi: 10.1002/ neu. 10141

117. Merten MD, Stocker-Buschina S. Fadrozole induces delayed effects on neurons in the zebra finch song system. Brain Res. (1995) 671:317-20. doi: 10.1016/0006-8993(94)01370-W

118. Wade J, Arnold AP. Post-hatching inhibition of aromatase activity does not alter sexual differentiation of the zebra finch song system. Brain Res. (1994) 639:347-50. doi: 10.1016/0006-8993(94)91752-3

119. Gong A, Freking FW, Wingfield J, Schlinger BA, Arnold AP. Effects of embryonic treatment with fadrozole on phenotype of gonads, syrinx, and neural song system in zebra finches. Gen Comp Endocrinol. (1999) 115:34653. doi: $10.1006 /$ gcen.1999.7318

120. Bailey DJ, Makeyeva YV, Paitel ER, Pedersen AL, Hon AT, Gunderson JA, et al. Hippocampal aromatization modulates spatial memory and characteristics of the synaptic membrane in the male zebra finch. Endocrinology (2017) 158:852-9. doi: 10.1210/en.2016-1692
121. Rensel MA, Ellis JM, Harvey B, Schlinger BA. Sex, estradiol, and spatial memory in a food-caching corvid. Horm Behav. (2015) 75:45-54. doi: 10.1016/j.yhbeh.2015.07.022

122. Rensel MA, Salwiczek L, Roth J, Schlinger BA. Context-specific effects of estradiol on spatial learning and memory in the zebra finch. Neurobiol Learn Mem. (2013) 100:41-7. doi: 10.1016/j.nlm.2012.12.005

123. Kravitz HM, Meyer PM, Seeman TE, Greendale GA, Sowers MR. Cognitive functioning and sex steroid hormone gene polymorphisms in women at midlife. Am J Med. (2006) 119:S94-102. doi: 10.1016/j.amjmed.2006.07.030

124. Chew SJ, Mello C, Nottebohm F, Jarvis E, Vicario DS. Decrements in auditory responses to a repeated conspecific song are long-lasting and require two periods of protein synthesis in the songbird forebrain. Proc Natl Acad Sci USA. (1995) 92:3406-10. doi: 10.1073/pnas.92.8.3406

125. Mello C, Nottebohm F, Clayton D. Repeated exposure to one song leads to a rapid and persistent decline in an immediate early gene's response to that song in zebra finch telencephalon. J Neurosci. (1995) 15:6919-25. doi: 10.1523/JNEUROSCI.15-10-06919.1995

126. Anthoni H, Sucheston LE, Lewis BA, Tapia-Paez I, Fan X, Zucchelli M, et al. The aromatase gene CYP19A1: several genetic and functional lines of evidence supporting a role in reading, speech and language. Behav Genet. (2012) 42:509-27. doi: 10.1007/s10519-012-9532-3

127. Butler HT, Warden DR, Hogervorst E, Ragoussis J, Smith AD, Lehmann DJ. Association of the aromatase gene with Alzheimer's disease in women. Neurosci Lett. (2010) 468:202-6. doi: 10.1016/j.neulet.2009.10.089

128. Linardi A, Damiani D, Longui CA. The use of aromatase inhibitors in boys with short stature: what to know before prescribing? Arch Endocrinol Metab. (2017) 61:391-7. doi: 10.1590/2359-3997000000284

129. Haas J, Casper RF. In vitro fertilization treatments with the use of clomiphene citrate or letrozole. Fertil Steril. (2017) 108:568-71. doi: 10.1016/j.fertnstert.2017.08.017

130. Shippen ER, West WJ Jr. Successful treatment of severe endometriosis in two premenopausal women with an aromatase inhibitor. Fertil Steril. (2004) 81:1395-8. doi: 10.1016/j.fertnstert.2003.11.027

131. Biri A, Korucuoglu U, Zumrutbas N, Tiras B, Guner H. Intravenous leiomyomatosis treated with aromatase inhibitor therapy. Int J Gynaecol Obstet. (2008) 101:299-300. doi: 10.1016/j.ijgo.2007.12.002

132. Mehta A, Clearman T, Paduch DA. Safety and efficacy of testosterone replacement therapy in adolescents with Klinefelter syndrome. J Urol. (2014) 191:1527-31. doi: 10.1016/j.juro.2013.09.015

133. Hero M, Maury S, Luotoniemi E, Service E, Dunkel L. Cognitive effects of aromatase inhibitor therapy in peripubertal boys. Eur J Endocrinol. (2010) 163:149-55. doi: 10.1530/EJE-10-0040

134. Gerard C, Brown KA. Obesity and breast cancer - Role of estrogens and the molecular underpinnings of aromatase regulation in breast adipose tissue. Mol Cell Endocrinol. (2017) 466:15-30. doi: 10.1016/j.mce.2017.09.014

135. Wang X, Simpson ER, Brown KA. Aromatase overexpression in dysfunctional adipose tissue links obesity to postmenopausal breast cancer. J Steroid Biochem Mol Biol. (2015) 153:35-44. doi: 10.1016/j.jsbmb.2015.07.008

136. Simpson ER, Brown KA. Obesity and breast cancer: role of inflammation and aromatase. J Mol Endocrinol. (2013) 51:T51-9. doi: 10.1210/me.2013-1011

137. Ioannides SJ, Barlow PL, Elwood JM, Porter D. Effect of obesity on aromatase inhibitor efficacy in postmenopausal, hormone receptor-positive breast cancer: a systematic review. Breast Cancer Res Treat. (2014) 147:237-48. doi: 10.1007/s10549-014-3091-7

138. Gallicchio L, Calhoun C, Helzlsouer K. A prospective study of aromatase inhibitor therapy initiation and self-reported side effects. Support Care Cancer (2017) 25:2697-705. doi: 10.1007/s00520-017-3678-8

139. Le Rhun E, Delbeuck X, Lefeuvre-Plesse C, Kramar A, Skrobala E, Pasquier $\mathrm{F}$, et al. A phase III randomized multicenter trial evaluating cognition in post-menopausal breast cancer patients receiving adjuvant hormonotherapy. Breast Cancer Res Treat. (2015) 152:569-80. doi: 10.1007/s10549-015-3493-1

140. Hertz DL, Henry NL, Rae JM. Germline genetic predictors of aromatase inhibitor concentrations, estrogen suppression and drug efficacy and toxicity in breast cancer patients. Pharmacogenomics (2017) 18:481-99. doi: $10.2217 /$ pgs-2016-0205

141. Schilder CM, Eggens PC, Seynaeve C, Linn SC, Boogerd W, Gundy CM, et al. Neuropsychological functioning in postmenopausal breast cancer 
patients treated with tamoxifen or exemestane after AC-chemotherapy: cross-sectional findings from the neuropsychological TEAM-side study. Acta Oncol. (2009) 48:76-85. doi: 10.1080/02841860802314738

142. Phillips KA, Aldridge J, Ribi K, Sun Z, Thompson A, Harvey V, et al. Cognitive function in postmenopausal breast cancer patients one year after completing adjuvant endocrine therapy with letrozole and/or tamoxifen in the BIG 1-98 trial. Breast Cancer Res Treat. (2011) 126:221-6. doi: 10.1007/s10549-010-1235-y

143. Ganz PA, Petersen L, Bower JE, Crespi CM. Impact of adjuvant endocrine therapy on quality of ILife and symptoms: observational data over 12 months from the mind-body study. J Clin Oncol. (2016) 34:816-24. doi: 10.1200/JCO.2015.64.3866

144. Shah S, Bell RJ, Savage G, Goldstat R, Papalia MA, Kulkarni $\mathrm{J}$, et al. Testosterone aromatization and cognition in women: a randomized, placebo-controlled trial. Menopause (2006) 13:600-8. doi: 10.1097/01.gme.0000227333.50867.4e

145. Kwan ML, Roh JM, Laurent CA, Lee J, Tang L, Hershman D, et al. Patterns and reasons for switching classes of hormonal therapy among women with early-stage breast cancer. Cancer Causes Control (2017) 28:557-62. doi: 10.1007/s10552-017-0888-9

146. Underwood EA, Rochon PA, Moineddin R, Lee PE, Wu W, Pritchard $\mathrm{KI}$, et al. Cognitive sequelae of endocrine therapy in women treated for breast cancer: a meta-analysis. Breast Cancer Res Treat. (2018) 168:299-310. doi: 10.1007/s10549-017-4627-4

147. Shilling V, Jenkins V, Fallowfield L, Howell T. The effects of hormone therapy on cognition in breast cancer. J Steroid Biochem Mol Biol. (2003) 86:405-12. doi: 10.1016/j.jsbmb.2003.07.001

148. Jenkins V, Shilling V, Fallowfield L, Howell A, Hutton S. Does hormone therapy for the treatment of breast cancer have a detrimental effect on memory and cognition? A pilot study. Psychooncology (2004) 13:61-6. doi: $10.1002 /$ pon.709

149. Rocha-Cadman X, Massie MJ, Du Hamel K. Aromatase inhibitors and mood disturbances. Palliat Support Care (2012) 10:225-7. doi: 10.1017/S1478951512000636

150. Jenkins VA, Ambroisine LM, Atkins L, Cuzick J, Howell A, Fallowfield LJ. Effects of anastrozole on cognitive performance in postmenopausal women: a randomised, double-blind chemoprevention trial (IBIS II). Lancet Oncol. (2008) 9:953-61. doi: 10.1016/S1470-2045(08)70207-9

151. Li C, Zhou C, Li R. Can exercise ameliorate aromatase inhibitor-induced cognitive decline in breast cancer pPatients? Mol Neurobiol. (2016) 53:423846. doi: 10.1007/s12035-015-9341-9

152. Barha CK, Falck RS, Davis JC, Nagamatsu LS, Liu-Ambrose T. Sex differences in aerobic exercise efficacy to improve cognition: a systematic review and meta-analysis of studies in older rodents. Front Neuroendocrinol. (2017) 46:86-105. doi: 10.1016/j.yfrne.2017.06.001

153. Brown JC, Mao JJ, Stricker C, Hwang WT, Tan KS, Schmitz KH. Aromatase inhibitor associated musculoskeletal symptoms are associated with reduced physical activity among breast cancer survivors. Breast J. (2014) 20:22-8. doi: $10.1111 /$ tbj. 12202

154. Evrard HC, Balthazart J. Rapid regulation of pain by estrogens synthesized in spinal dorsal horn neurons. J Neurosci. (2004) 24:7225-9. doi: 10.1523/JNEUROSCI.1638-04.2004

155. Ghorbanpoor S, Garcia-Segura LM, Haeri-Rohani A, Khodagholi F, Jorjani M. Aromatase inhibition exacerbates pain and reactive gliosis in the dorsal horn of the spinal cord of female rats caused by spinothalamic tract injury. Endocrinology (2014) 155:4341-55. doi: 10.1210/en.2014-1158

156. O’brien EE, Smeester BA, Michlitsch KS, Lee JH, Beitz AJ. Colocalization of aromatase in spinal cord astrocytes: differences in expression and relationship to mechanical and thermal hyperalgesia in murine models of a painful and a non-painful bone tumor. Neuroscience (2015) 301:235-45. doi: 10.1016/j.neuroscience.2015.06.009

157. Choi HS, Lee MJ, Choi SR, Smeester BA, Beitz AJ, Lee JH. Spinal sigma1 receptor-mediated dephosphorylation of astrocytic aromatase plays a key role in formalin-induced inflammatory nociception. Neuroscience (2018) 372:181-91. doi: 10.1016/j.neuroscience.2017.12.031

158. Fusi C, Materazzi S, Benemei S, Coppi E, Trevisan G, Marone IM, et al. Steroidal and non-steroidal third-generation aromatase inhibitors induce pain-like symptoms via TRPA1. Nat Commun. (2014) 5:5736. doi: $10.1038 /$ ncomms6736

159. Robarge JD, Duarte DB, Shariati B, Wang R, Flockhart DA, Vasko MR. Aromatase inhibitors augment nociceptive behaviors in rats and enhance the excitability of sensory neurons. Exp Neurol. (2016) 281:53-65. doi: 10.1016/j.expneurol.2016.04.006

160. Xu P, Cao X, He Y, Zhu L, Yang Y, Saito K, et al. Estrogen receptor-alpha in medial amygdala neurons regulates body weight. J Clin Invest. (2015) 125:2861-76. doi: 10.1172/JCI80941

161. Giles ED, Jackman MR, Johnson GC, Schedin PJ, Houser JL, MacLean PS. Effect of the estrous cycle and surgical ovariectomy on energy balance, fuel utilization, and physical activity in lean and obese female rats. Am J Physiol Regul Integr Comp Physiol. (2010) 299:R1634-1642. doi: 10.1152/ajpregu.00219.2010

162. Bowen RS, Ferguson DP, Lightfoot JT. Effects of aromatase inhibition on the physical activity levels of male mice. J Steroids Horm Sci. (2011) 1:1-7. doi: 10.4172/2157-7536.S1-001

163. Jones ME, Thorburn AW, Britt KL, Hewitt KN, Wreford NG, Proietto J, et al. Aromatase-deficient (ArKO) mice have a phenotype of increased adiposity. Proc Natl Acad Sci USA. (2000) 97:12735-40. doi: 10.1073/pnas.97.23.12735

164. De Paulo TRS, Viezel J, Aro BL, Seidinger SC, Trindade A, Christofaro DGD, et al. Relationship between physical activity practice and metabolic profile of postmenopausal women under treatment with aromatase inhibitors for breast cancer. Eur J Obstet Gynecol Reprod Biol. (2017) 216:33-7. doi: 10.1016/j.ejogrb.2017.07.003

165. Raichlen DA, Alexander GE. Adaptive capacity: an evolutionary neuroscience model linking exercise, cognition, and brain health. Trends Neurosci. (2017) 40:408-21. doi: 10.1016/j.tins.2017.05.001

166. Nichol K, Deeny SP, Seif J, Camaclang K, Cotman CW. Exercise improves cognition and hippocampal plasticity in APOE epsilon4 mice. Alzheimers Dement. (2009) 5:287-94. doi: 10.1016/j.jalz.2009.02.006

167. Lafenetre P, Leske O, Ma-Hogemeie Z, Haghikia A, Bichler Z, Wahle P, et al. Exercise can rescue recognition memory impairment in a model with reduced adult hippocampal neurogenesis. Front Behav Neurosci. (2010) 3:34. doi: 10.3389/neuro.08.034.2009

168. Kobilo T, Yuan C, Van Praag H. Endurance factors improve hippocampal neurogenesis and spatial memory in mice. Learn Mem. (2011) 18:103-7. doi: 10.1101/lm.2001611

169. Sato K, Akaishi T, Matsuki N, Ohno Y, Nakazawa K. beta-Estradiol induces synaptogenesis in the hippocampus by enhancing brain-derived neurotrophic factor release from dentate gyrus granule cells. Brain Res. (2007) 1150:108-20. doi: 10.1016/j.brainres.2007.02.093

170. Sellers KJ, Erli F, Raval P, Watson IA, Chen D, Srivastava DP. Rapid modulation of synaptogenesis and spinogenesis by $17 \beta$-estradiol in primary cortical neurons. Front Cell Neurosci. (2015) 9:137. doi: 10.3389/fncel.2015.00137

171. McEwen BS. Sex, stress and the brain: interactive actions of hormones on the developing and adult brain. Climacteric (2014) 17(Suppl. 2):18-25. doi: 10.3109/13697137.2014.949662

172. Dominguez R, Zitting M, Liu Q, Patel A, Babadjouni R, Hodis DM, et al. Estradiol protects white matter of male C57BL6J mice against experimental chronic cerebral hypoperfusion. J Stroke Cerebrovasc Dis. (2018) 27:1743-51. doi: 10.1016/j.jstrokecerebrovasdis.2018.01.030

173. Kretz O, Fester L, Wehrenberg U, Zhou L, Brauckmann S, Zhao $\mathrm{S}$, et al. Hippocampal synapses depend on hippocampal estrogen synthesis. J Neurosci. (2004) 24:5913-21. doi: 10.1523/JNEUROSCI.518603.2004

174. Prange-Kiel J, Rune GM. Direct and indirect effects of estrogen on rat hippocampus. Neuroscience (2006) 138:765-72. doi: 10.1016/j.neuroscience.2005.05.061

175. Fester L, Brandt N, Windhorst S, Prols F, Blaute C, Rune GM. Control of aromatase in hippocampal neurons. J Steroid Biochem Mol Biol. (2016) 160:9-14. doi: 10.1016/j.jsbmb.2015.10.009

176. Bauml J, Chen L, Chen J, Boyer J, Kalos M, Li SQ, et al. Arthralgia among women taking aromatase inhibitors: is there a shared inflammatory mechanism with co-morbid fatigue and insomnia? Breast Cancer Res. (2015) 17:89. doi: 10.1186/s13058-015-0599-7 
177. Hershman DL, Loprinzi C, Schneider BP. Symptoms: Aromatase inhibitor induced arthralgias. Adv Exp Med Biol. (2015) 862:89-100. doi: 10.1007/978-3-319-16366-6_7

178. Irwin ML, Cartmel B, Gross CP, Ercolano E, Li F, Yao X, et al. Randomized exercise trial of aromatase inhibitor-induced arthralgia in breast cancer survivors. J Clin Oncol. (2015) 33:1104-11. doi: 10.1200/JCO.2014.57.1547

179. Thomas GA, Cartmel B, Harrigan M, Fiellin M, Capozza S, Zhou Y, et al. The effect of exercise on body composition and bone mineral density in breast cancer survivors taking aromatase inhibitors. Obesity (2017) 25:346-51. doi: 10.1002/oby.21729

180. Gentry AL, Erickson KI, Sereika SM, Casillo FE, Crisafio ME, Donahue PT, et al. Protocol for exercise program in cancer and cognition (EPICC): a randomized controlled trial of the effects of aerobic exercise on cognitive function in postmenopausal women with breast cancer receiving aromatase inhibitor therapy. Contemp Clin Trials (2018) 67:109-15. doi: 10.1016/j.cct.2018.02.012

181. Janicki SC, Park N, Cheng R, Schupf N, Clark LN, Lee JH. Aromatase variants modify risk for Alzheimer's disease in a multiethnic female cohort. Dement Geriatr Cogn Disord. (2013) 35:340-6. doi: 10.1159/000343074

182. Iivonen S, Corder E, Lehtovirta M, Helisalmi S, Mannermaa A, Vepsalainen S, et al. Polymorphisms in the CYP19 gene confer increased risk for Alzheimer disease. Neurology (2004) 62:1170-6. doi: 10.1212/01.WNL.0000118208.16939.60

183. Combarros O, Riancho JA, Infante J, Sanudo C, Llorca J, Zarrabeitia MT, et al. Interaction between CYP19 aromatase and butyrylcholinesterase genes increases Alzheimer's disease risk. Dement Geriatr Cogn Disord. (2005) 20:153-7. doi: 10.1159/000087065

184. Huang R, Poduslo SE. CYP19 haplotypes increase risk for Alzheimer's disease. J Med Genet. (2006) 43:e42. doi: 10.1136/jmg.2005.039461

185. Combarros O, Sanchez-Juan P, Riancho JA, Mateo I, Rodriguez-Rodriguez E, Infante J, et al. Aromatase and interleukin-10 genetic variants interactively modulate Alzheimer's disease risk. J Neural Transm. (2008) 115:863-7. doi: 10.1007/s00702-008-0028-5

186. Corbo RM, Gambina G, Ulizzi L, Moretto G, Scacchi R. Genetic variation of CYP19 (aromatase) gene influences age at onset of Alzheimer's disease in women. Dement Geriatr Cogn Disord. (2009) 27:513-8. doi: $10.1159 / 000221832$

187. Chace C, Pang D, Weng C, Temkin A, Lax S, Silverman W, et al. Variants in CYP17 and CYP19 cytochrome P450 genes are associated with onset of Alzheimer's disease in women with down syndrome. J Alzheimers Dis. (2012) 28:601-12. doi: 10.3233/JAD-2011-110860

188. Medway C, Combarros O, Cortina-Borja M, Butler HT, Ibrahim-Verbaas CA, De Bruijn RF, et al. The sex-specific associations of the aromatase gene with Alzheimer's disease and its interaction with IL10 in the Epistasis Project. Eur J Hum Genet. (2014) 22:216-20. doi: 10.1038/ejhg.2013.116

189. Zheng J, Yan H, Shi L, Kong Y, Zhao Y, Xie L, et al. The CYP19A1 rs3751592 variant confers susceptibility to Alzheimer disease in the Chinese Han population. Medicine (2016) 95:e4742. doi: 10.1097/MD.0000000000004742

190. Prange-Kiel J, Dudzinski DA, Prols F, Glatzel M, Matschke J, Rune GM. Aromatase expression in the hippocampus of AD patients and 5xFAD mice. Neural Plast. (2016) 2016:11. doi: 10.1155/2016/9802086

191. Overk CR, Lu PY, Wang YT, Choi J, Shaw JW, Thatcher GR, et al. Effects of aromatase inhibition versus gonadectomy on hippocampal complex amyloid pathology in triple transgenic mice. Neurobiol Dis. (2012) 45:47987. doi: 10.1016/j.nbd.2011.08.035

192. Prat A, Behrendt M, Marcinkiewicz E, Boridy S, Sairam RM, Seidah NG, et al. A novel mouse model of Alzheimer's disease with chronic estrogen deficiency leads to glial cell activation and hypertrophy. J Aging Res. (2011) 2011:251517. doi: 10.4061/2011/251517

193. Yue X, Lu M, Lancaster T, Cao P, Honda S, Staufenbiel M, et al. Brain estrogen deficiency accelerates Abeta plaque formation in an Alzheimer's disease animal model. Proc Natl Acad Sci USA. (2005) 102:19198-203. doi: 10.1073/pnas.0505203102

194. Li R, He P, Cui J, Staufenbiel M, Harada N, Shen Y. Brain endogenous estrogen levels determine responses to estrogen replacement therapy via regulation of BACE1 and NEP in female Alzheimer's transgenic mice. $\mathrm{Mol}$ Neurobiol. (2013) 47:857-67. doi: 10.1007/s12035-012-8377-3

195. McAllister C, Long J, Bowers A, Walker A, Cao P, Honda S, et al. Genetic targeting aromatase in male amyloid precursor protein transgenic mice down-regulates beta-secretase (BACE1) and prevents Alzheimerlike pathology and cognitive impairment. J Neurosci. (2010) 30:7326-34. doi: 10.1523/JNEUROSCI.1180-10.2010

196. Clarke R, Smith AD, Jobst KA, Refsum H, Sutton L, Ueland PM. Folate, vitamin B12, and serum total homocysteine levels in confirmed Alzheimer disease. Arch Neurol. (1998) 55:1449-55. doi: 10.1001/archneur.55.11.1449

197. Ishunina TA, Van Beurden D, Van Der Meulen G, Unmehopa UA, Hol EM, Huitinga I, et al. Diminished aromatase immunoreactivity in the hypothalamus, but not in the basal forebrain nuclei in Alzheimer's disease. Neurobiol Aging (2005) 26:173-94. doi: 10.1016/j.neurobiolaging.2004.03.010

198. Ishunina TA, Fischer DF, Swaab DF. Estrogen receptor alpha and its splice variants in the hippocampus in aging and Alzheimer's disease. Neurobiol Aging (2007) 28:1670-81. doi: 10.1016/j.neurobiolaging.2006.07.024

199. Wozniak A, Hutchison RE, Morris CM, Hutchison JB. Neuroblastoma and Alzheimer's disease brain cells contain aromatase activity. Steroids (1998) 63:263-7. doi: 10.1016/S0039-128X(98)00029-4

200. Luchetti S, Bossers K, Van De Bilt S, Agrapart V, Morales RR, Frajese GV, et al. Neurosteroid biosynthetic pathways changes in prefrontal cortex in Alzheimer's disease. Neurobiol Aging (2011) 32:1964-76. doi: 10.1016/j.neurobiolaging.2009.12.014

201. Honda S, Harada N, Ito S, Takagi Y, Maeda S. Disruption of sexual behavior in male aromatase-deficient mice lacking exons 1 and 2 of the cyp19 gene. Biochem Biophys Res Commun. (1998) 252:445-9. doi: 10.1006/bbrc.1998.9672

202. Bakker J, Honda S, Harada N, Balthazart J. Restoration of male sexual behavior by adult exogenous estrogens in male aromatase knockout mice. Horm Behav. (2004) 46:1-10. doi: 10.1016/j.yhbeh.2004.02.003

203. Farman HH, Windahl SH, Westberg L, Isaksson H, Egecioglu E, Schele $\mathrm{E}$, et al. Female mice lacking estrogen receptor-alpha in hypothalamic proopiomelanocortin (POMC) neurons display enhanced estrogenic response on cortical bone mass. Endocrinology (2016) 157:3242-52. doi: 10.1210/en.2016-1181

204. Nakata M, Sano K, Musatov S, Yamaguchi N, Sakamoto T, Ogawa S. Effects of prepubertal or adult site-specific knockdown of estrogen receptor $\beta$ in the medial preoptic area and medial amygdala on social behaviors in male mice. eNeuro (2016) 3. doi: 10.1523/ENEURO.0155-15.2016

205. Sano K, Nakata M, Musatov S, Morishita M, Sakamoto T, Tsukahara $\mathrm{S}$, et al. Pubertal activation of estrogen receptor alpha in the medial amygdala is essential for the full expression of male social behavior in mice. Proc Natl Acad Sci USA. (2016) 113:7632-7. doi: 10.1073/pnas.152 4907113

206. Kesslak JP. Can estrogen play a significant role in the prevention of Alzheimer's disease? J Neural Transm Suppl. (2002) 62: 227-39. doi: 10.1007/978-3-7091-6139-5_21

207. Garcia-Segura LM, Wozniak A, Azcoitia I, Rodriguez JR, Hutchison RE, Hutchison JB. Aromatase expression by astrocytes after brain injury: implications for local estrogen formation in brain repair. Neuroscience (1999) 89:567-78. doi: 10.1016/S0306-4522(98)00340-6

Conflict of Interest Statement: The authors declare that the research was conducted in the absence of any commercial or financial relationships that could be construed as a potential conflict of interest.

Copyright (c) 2018 Rosenfeld, Shay and Vieira-Potter. This is an open-access article distributed under the terms of the Creative Commons Attribution License (CC BY). The use, distribution or reproduction in other forums is permitted, provided the original author(s) and the copyright owner(s) are credited and that the original publication in this journal is cited, in accordance with accepted academic practice. No use, distribution or reproduction is permitted which does not comply with these terms. 